\title{
Potentiometric CO sensors using anion-conducting polymer electrolyte: Effects of the kinds of noble metal-loaded metal oxides as sensing-electrode materials on CO-sensing properties
}

Takeo Hyodo*, Mari Takamori, Toshiyuki Goto, Taro Ueda, and Yasuhiro Shimizu

Graduate School of Engineering, Nagasaki University

1-14 Bunkyo-machi, Nagasaki 852-8521, Japan

*Corresponding author:

Takeo Hyodo, Dr.

Graduate School of Engineering, Nagasaki University

1-14 Bunkyo-machi, Nagasaki 852-8521, Japan

Tel: +81-95-819-2644

Fax: +81-95-819-2643

E-mail: hyodo@nagasaki-u.ac.jp 


\section{Abstract}

Potentiometric CO-sensing properties of electrochemical gas sensors using an anionconducting polymer as an electrolyte and a metal oxide $\left(\mathrm{MO} ; \mathrm{Bi}_{2} \mathrm{O}_{3}, \mathrm{CeO}_{2}, \mathrm{In}_{2} \mathrm{O}_{3}, \mathrm{SnO}_{2}\right.$, or $\mathrm{V}_{2} \mathrm{O}_{5}$ ) loaded with or without $2.0 \mathrm{wt} \%$ noble metal (N; $\mathrm{Ag}, \mathrm{Au}, \mathrm{Ir}, \mathrm{Ru}, \mathrm{Rh}, \mathrm{Pd}$, or Pt) as an electrode material (EC(N/MO) or (EC(MO) sensor; N/MO: N-loaded MO) were investigated in wet synthetic air $(57 \% \mathrm{RH})$ at $30^{\circ} \mathrm{C}$. Among all the $\mathrm{EC}(\mathrm{MO})$ sensors, the $\mathrm{EC}\left(\mathrm{CeO}_{2}\right)$ sensor showed the largest $\mathrm{CO}$ response and excellent $\mathrm{CO}$ selectivity against $\mathrm{H}_{2}$ and the $\mathrm{EC}\left(\mathrm{Bi}_{2} \mathrm{O}_{3}\right)$ sensor showed relatively large $\mathrm{CO}$ and $\mathrm{H}_{2}$ responses (no $\mathrm{CO}$ selectivity against $\mathrm{H}_{2}$ ). Other EC(MO) sensors hardly showed both $\mathrm{CO}$ and $\mathrm{H}_{2}$ responses. However, the Au loading just onto $\mathrm{In}_{2} \mathrm{O}_{3}$ and $\mathrm{SnO}_{2}$ was effective in improving the magnitude of $\mathrm{CO}$ and $\mathrm{H}_{2}$ responses of the $\mathrm{EC}\left(\mathrm{In}_{2} \mathrm{O}_{3}\right)$ and $\mathrm{EC}\left(\mathrm{SnO}_{2}\right)$ sensors, respectively, which resulted in relatively poor CO selectivity against $\mathrm{H}_{2}$. On the other hand, the Pt loading only onto $\mathrm{SnO}_{2}$ extremely enhanced only the magnitude of $\mathrm{CO}$ response of the $\mathrm{EC}\left(\mathrm{SnO}_{2}\right)$ sensor, and thus the $\mathrm{EC}\left(\mathrm{Pt} / \mathrm{SnO}_{2}\right)$ sensor showed the most excellent $\mathrm{CO}$ selectivity against $\mathrm{H}_{2}$, among all the sensors in this study. The heat treatment of N/MO powders in $\mathrm{H}_{2}$ at $250^{\circ} \mathrm{C}$ reduced only the $\mathrm{H}_{2}$ response of the $\mathrm{EC}\left(\mathrm{Au} / \mathrm{SnO}_{2}\right)$ sensor, leading to an improvement of the $\mathrm{CO}$ selectivity of only the $\mathrm{EC}\left(\mathrm{Au} / \mathrm{SnO}_{2}\right)$ sensor against $\mathrm{H}_{2}$. On the other hand, the heat treatment drastically enhanced both $\mathrm{CO}$ and $\mathrm{H}_{2}$ responses of the $\mathrm{EC}\left(\mathrm{Pt} / \mathrm{SnO}_{2}\right)$ sensor, resulting in a decrease in its $\mathrm{CO}$ selectivity against $\mathrm{H}_{2}$. The $\mathrm{CO}$ and $\mathrm{H}_{2}$ responses of other $\mathrm{EC}\left(\mathrm{N} / \mathrm{SnO}_{2}\right)$ sensors before and after the heat treatment in $\mathrm{H}_{2}$ at $250^{\circ} \mathrm{C}$ were also examined, and the effectiveness of the noble metal loading and the heat treatment on the CO-sensing properties was discussed in this study. In addition, gas-sensing mechanism was also proposed on the basis of chemical surface states of representative N/MO.

Keywords: Potentiometric gas sensor; Anion-conducting polymer; Carbon monoxide; Metal oxide; Noble metal 


\section{Introduction}

Carbon monoxide (CO) is extremely harmful to human health, because $\mathrm{CO}$ can quickly combine with hemoglobin in human blood and then seriously interfere with the transport of oxygen to tissues in human body [1]. However, we cannot detect $\mathrm{CO}$, which is odorless and colorless, by ourselves, and thus highly sensitive and selective CO sensors are quite essential in detecting even a low concentration of CO quickly and accurately, and then in preventing inhalation of $\mathrm{CO}$ into lung through the respiratory system. Among various types of $\mathrm{CO}$ sensors [2-6], electrochemical gas sensors using cation-conducting polymer (such as Nafion ${ }^{\circledR}$ ) as an electrolyte material, which can be operated at RT, have also been attractive as a high performance CO sensor [7-13], and some types of electrochemical CO sensors are presently commercialized all over the world [14]. On the other hand, anion-conducting polymers (ACP) with large $\mathrm{OH}^{-}$conductivity and improved long-term stability [15-17] are also quite attractive as an electrolyte material alternative to cation-conducting polymers, because most of metal oxides are relatively stable in alkaline media. We have already demonstrated that potentiometric gas sensors employing the ACP electrolyte and Pd- or Pt-loaded carbon-black electrodes showed relatively large responses to $\mathrm{H}_{2}$ [18], $\mathrm{CO}$ [19], and $\mathrm{CO}_{2}$ [20], respectively, but gas selectivity of these sensors was really poor. Therefore, we have recently investigated COsensing properties of the ACP-based sensors using a metal oxide $\left(\mathrm{Co}_{3} \mathrm{O}_{4}, \mathrm{In}_{2} \mathrm{O}_{3}, \mathrm{SnO}_{2}\right.$, or $\left.\mathrm{ZnO}\right)$ loaded with Au nanoparticles as a CO-sensing electrode material, and reported that the use of Au-loaded $\mathrm{In}_{2} \mathrm{O}_{3}$ or $\mathrm{SnO}_{2}$ electrodes drastically enhanced the magnitude of $\mathrm{CO}$ response as well as $\mathrm{CO}$ selectivity against $\mathrm{H}_{2}$ after heat treatment of the Au-loaded $\mathrm{In}_{2} \mathrm{O}_{3}$ or $\mathrm{SnO}_{2}$ powder under a reducing atmosphere at an elevated temperature $\left(250^{\circ} \mathrm{C}\right)[21,22]$. These results obviously show that such metal-oxide-based materials have substantial advantage in the CO-sensing properties (especially, the $\mathrm{CO}$ selectivity against $\mathrm{H}_{2}$ ), as a $\mathrm{CO}$-sensing electrode substrate of potentiometric gas sensors, in comparison with carbon-black-based materials. 
Therefore, we have attempted to find promising metal oxides loaded with noble metal as a highly sensitive and selective CO-sensing electrode material of potentiometric gas sensors in this study. First, we have discussed effects of the kind of metal oxide $\left(\mathrm{Bi}_{2} \mathrm{O}_{3}, \mathrm{CeO}_{2}, \mathrm{In}_{2} \mathrm{O}_{3}, \mathrm{SnO}_{2}\right.$, or $\mathrm{V}_{2} \mathrm{O}_{5}$ ) as a base material of the sensing electrode on the $\mathrm{CO}$-sensing properties of the ACPbased sensors. In addition, the impacts of the kind of noble metal ( $\mathrm{Ag}, \mathrm{Au}, \mathrm{Ir}, \mathrm{Ru}, \mathrm{Rh}, \mathrm{Pd}$, or Pt) loaded onto the $\mathrm{SnO}_{2}$ powder and the heat-treatment conditions on their $\mathrm{CO}$-sensing properties have been also investigated.

\section{Experimental}

\subsection{Preparation of metal-oxide (MO) powders}

Five kinds of $\mathrm{MO}$ powders $\left(\mathrm{Bi}_{2} \mathrm{O}_{3}, \mathrm{CeO}_{2}, \mathrm{In}_{2} \mathrm{O}_{3}, \mathrm{SnO}_{2}, \mathrm{~V}_{2} \mathrm{O}_{5}\right)$ were prepared according to the following procedure.

$\left[\mathbf{B i}_{2} \mathbf{O}_{3}\right]$ The $\mathrm{pH}$ of a $0.20 \mathrm{M} \mathrm{Bi}\left(\mathrm{NO}_{3}\right)_{3}$ aqueous solution was adjusted to 11 by the addition of a $\mathrm{NaOH}$ aqueous solution. The obtained precipitate was centrifuged and washed with pure water repeatedly, and then it was dried at $100^{\circ} \mathrm{C}$. The resultant dried powder was calcined at $500^{\circ} \mathrm{C}$ for $3 \mathrm{~h}$ in air, to obtain a $\mathrm{Bi}_{2} \mathrm{O}_{3}$ powder.

[CeO $\mathrm{CeO}_{2}$ A $0.02 \mathrm{~mol} \mathrm{Ce}\left(\mathrm{NO}_{3}\right)_{3} \cdot 6 \mathrm{H}_{2} \mathrm{O}$ was dissolved into ethanol $\left(30 \mathrm{~cm}^{3}\right)$, and then $0.16 \mathrm{~mol}$ triethanolamine and $300 \mathrm{~cm}^{3}$ pure water were added into the solution. The obtained precipitate was centrifuged and washed with pure water and methanol sometimes. $\mathrm{A} \mathrm{CeO}_{2}$ powder was prepared by the calcination of the resultant powder at $700^{\circ} \mathrm{C}$ for $2 \mathrm{~h}$ in air.

$\left[\mathbf{I n}_{2} \mathrm{O}_{3}\right.$ and $\mathbf{S n O}_{2}$ ] The $\mathrm{pH}$ of $0.35 \mathrm{M} \mathrm{In}\left(\mathrm{NO}_{3}\right)_{3}$ or $0.17 \mathrm{M} \mathrm{SnCl}_{4}$ aqueous solution was adjusted to 3.5 and 2.0, respectively, by the addition of a $\mathrm{NH}_{3}$ aqueous solution. The obtained precipitate was centrifuged and washed with pure water repeatedly, and then dried at $100^{\circ} \mathrm{C}$. Then, $\mathrm{In}_{2} \mathrm{O}_{3}$ or $\mathrm{SnO}_{2}$ powder was prepared by the calcination of the resultant powder at $500^{\circ} \mathrm{C}$ for $3 \mathrm{~h}$ in air. $\left[\mathbf{V}_{2} \mathbf{O}_{5}\right]$ After an appropriate amount of $\mathrm{NH}_{4} \mathrm{VO}_{3}$ and oxalic acid was added into pure water, the 
solution was evaporated to dryness. The obtained precipitate was centrifuged and washed with pure water repeatedly, and then dried at $100^{\circ} \mathrm{C}$. After crushing the resultant solid by using an agate mortar, a $\mathrm{V}_{2} \mathrm{O}_{5}$ powder were prepared by the calcination of the powder at $500^{\circ} \mathrm{C}$ for $3 \mathrm{~h}$ in air.

\subsection{Preparation of MO powders loaded with $2 \mathrm{wt} \%$ noble metal (N)}

Loading of $\mathrm{Au}$ nanoparticles on the MO powders was only performed by general precipitation-deposition technique [23]. After the $\mathrm{pH}$ value of a $1 \mathrm{mM} \mathrm{HAuCl}_{4}$ aqueous solution at $70^{\circ} \mathrm{C}$ was adjusted to 4 by addition of a $\mathrm{NH}_{3}$ aqueous solution, the $\mathrm{MO}$ powder $(2.0 \mathrm{~g})$ was added to the solution $\left(197 \mathrm{~cm}^{3}\right)$. The $\mathrm{pH}$ value of the solution was adjusted to 7.0 by further addition of an $\mathrm{NH}_{3}$ aqueous solution and the solution was stirred at $70^{\circ} \mathrm{C}$ for $1 \mathrm{~h}$, to deposit $\mathrm{Au}-$ based precipitates $\left(\mathrm{Au}(\mathrm{OH})_{3}\right)$ on the surface of the MO powder, and then it was centrifuged and repeatedly washed with pure water. The obtained powder was dried at $100^{\circ} \mathrm{C}$ and then heattreated at $400^{\circ} \mathrm{C}$ for $1 \mathrm{~h}$ in air or at $250^{\circ} \mathrm{C}$ for $1 \mathrm{~h}$ in $\mathrm{H}_{2}$, to obtain $2 \mathrm{wt} \%$ Au-loaded MO powders. Their powders heat-treated in air or $\mathrm{H}_{2}$ was referred to as $\mathrm{Au} / \mathrm{MO}$ or $\mathrm{Au} / \mathrm{MO}-\mathrm{h}$, respectively. Other N-loaded MO powders were prepared by general impregnation technique. After an appropriate amount of each $\mathrm{MO}$ powder was added to a $1 \mathrm{mM} \mathrm{Ag}\left(\mathrm{NO}_{3}\right), \mathrm{IrCl}_{3}, \mathrm{RuCl}_{3}, \mathrm{RhCl}_{4}$, $\mathrm{Pd}\left(\mathrm{NO}_{3}\right)_{2}$, or $\mathrm{PtCl}_{4}$ aqueous solution, the obtained solution containing a $\mathrm{MO}$ powder was ultrasonicated at RT for 10 min and then it was evaporated to dryness. Then, the resultant solid was heat-treated in air at $500^{\circ} \mathrm{C}$ for $1 \mathrm{~h}$ or in $\mathrm{H}_{2}$ at $250^{\circ} \mathrm{C}$ for $1 \mathrm{~h}$. The obtained $2.0 \mathrm{wt} \% \mathrm{~N}$ loaded MO powders heat-treated in air or $\mathrm{H}_{2}$ were denoted as N/MO or N/MO-h, respectively.

\subsection{Characterization of all powders}

Crystal phases of all powders prepared were characterized by X-ray diffraction analysis (XRD; Rigaku Corp., RINT2200) using $\mathrm{Cu} \mathrm{K \alpha}$ radiation $(40 \mathrm{kV}, 36 \mathrm{~mA})$, and their crystallite 
sizes (CS) were calculated by utilizing the Scherrer equation (shaper factor: 0.9). Pore size distributions and specific surface areas (SSA) of all the powders were measured by general Barrett-Joyner-Halenda (BJH) and Brunauer-Emmett-Teller (BET) methods using $\mathrm{N}_{2}$ adsorption-desorption isotherms (Micromeritics Inst. Corp., TriStar 3000), respectively. Chemical states of elements on the surface of representative N/MO powders $(\mathrm{N}: \mathrm{Au}$ and $\mathrm{Pt}$, MO: $\mathrm{Bi}_{2} \mathrm{O}_{3}, \mathrm{In}_{2} \mathrm{O}_{3}$, and $\mathrm{SnO}_{2}$ ) were characterized by X-ray photoelectron spectroscopy using $\mathrm{Al} \mathrm{K} \alpha$ radiation (XPS, Kratos, ACIS-TLATRA DLD), and the binding energy was calibrated using the $\mathrm{C} 1 \mathrm{~s}$ level $(285.0 \mathrm{eV})$ from usual contamination.

\subsection{Fabrication of potentiometric gas sensors and measurement of their $\mathrm{CO}$ - and $\mathrm{H}_{2}$ - sensing properties}

A schematic drawing of a sensor element, or an electrochemical cell, is shown in Fig. 1(a). The MO or N/MO powder was mixed with an ACP solution (AS-4, Tokuyama Corp.), which is an iso-propanol containing a $5 \mathrm{wt} \%$ hydrocarbon-type ionic polymer with quaternary ammonium salts (MO or N/MO powder : $\mathrm{ACP}=95: 5$ in weight $)[15,16]$. The paste obtained was applied on the surface of both sides of an ACP membrane (A201, Tokuyama Corp., a polyolefin polymer film which consists of hydrocarbon main chain and quaternary ammonium salts, thickness: ca. $30 \mu \mathrm{m}[15,16])$ as sensing and counter electrodes by blade coating, and then it was dried at ca. $50^{\circ} \mathrm{C}$ for $30 \mathrm{~min}$. The sensor element fabricated with $\mathrm{MO}$ or N/MO powder was denoted as EC(MO) or EC(N/MO), respectively (EC stands for electrochemical cell). In addition, the sensor element was also fabricated by utilizing commercial Au paste (TR1403, Tanaka Kikinzoku Kogyo K.K.) or Pt paste (TR-7907, Tanaka Kikinzoku Kogyo K.K.) as a blade-coating material, and it was denoted as $\mathrm{EC}(\mathrm{Au})$ or $\mathrm{EC}(\mathrm{Pt})$, respectively.

A schematic drawing of a gas-sensing measurement system with two electrode compartments is shown in Fig. 1(b). The fabricated sensor element was sandwiched with Au 
meshes (Nilaco, 100 mesh) as a current collector and was set up in a gas-sensing measurement system with two electrode compartments. Electromotive force $(E)$ of all sensors to $\mathrm{CO}$ or $\mathrm{H}_{2}$ (10-3000 ppm) balanced with wet synthetic air $\left(\mathrm{O}_{2}: 20 \%, \mathrm{~N}_{2}: 80 \%\right.$, relative humidity: $57 \% \mathrm{RH}$ at $30^{\circ} \mathrm{C}$ ), which was flowed over the sensing electrode, was measured at $30^{\circ} \mathrm{C}$ by using a digital electrometer (ADCMT, 8240), while the wet synthetic air was flowed over the counter electrode. The magnitude of response was defined as a change in $E$ value induced by a sample gas ( $\Delta E_{\mathrm{SG}}$, SG (sample gas): $\mathrm{CO}$ or $\mathrm{H}_{2}$ ). $\mathrm{CO}$ selectivity against $\mathrm{H}_{2}$ was defined as a ratio of $\mathrm{CO}$ response to $\mathrm{H}_{2}$ response $\left(\Delta E_{\mathrm{CO}} / \Delta E_{\mathrm{H}_{2}}\right)$.

\section{Results and Discussions}

\subsection{CO-sensing properties of EC(MO) sensors and effects of Au or Pt loading onto MO}

Figure S1 shows XRD spectra of all MO powders, together with their crystallite sizes (CS) which were calculated from (120), (111), (222), (110), and (110) diffraction peaks of $\mathrm{Bi}_{2} \mathrm{O}_{3}$, $\mathrm{CeO}_{2}, \mathrm{In}_{2} \mathrm{O}_{3}, \mathrm{SnO}_{2}$, and $\mathrm{V}_{2} \mathrm{O}_{5}$ powders, respectively. In addition, Figure $\mathrm{S} 2$ shows $\mathrm{N}_{2}$ adsorption-desorption isotherms and pore-size distributions of their powders, together with their specific surface areas (SSA). The XRD spectrum of each MO powder, which was prepared with a $\mathrm{Bi}\left(\mathrm{NO}_{3}\right)_{3}, \mathrm{Ce}\left(\mathrm{NO}_{3}\right)_{3}, \mathrm{In}\left(\mathrm{NO}_{3}\right)_{3}, \mathrm{SnCl}_{4}$, or $\mathrm{NH}_{4} \mathrm{VO}_{3}$ aqueous solution was attributed to a single phase of $\mathrm{Bi}_{2} \mathrm{O}_{3}$ (JCPDS No. 71-2274), $\mathrm{CeO}_{2}$ (JCPDS No. 65-5923), $\mathrm{In}_{2} \mathrm{O}_{3}$ (JCPDS No. 89-4595), $\mathrm{SnO}_{2}$ (JCPDS No. 41-1445), or $\mathrm{V}_{2} \mathrm{O}_{5}$ (JCPDS No. 41-1426), respectively. The CS value of the prepared $\mathrm{Bi}_{2} \mathrm{O}_{3}, \mathrm{CeO}_{2}, \mathrm{In}_{2} \mathrm{O}_{3}, \mathrm{SnO}_{2}$, or $\mathrm{V}_{2} \mathrm{O}_{5}$ powder was ca. 54.5, 25.5, 19.8, 8.9, or $71.6 \mathrm{~nm}$, respectively. On the other hand, the SSA value of the prepared $\mathrm{Bi}_{2} \mathrm{O}_{3}, \mathrm{CeO}_{2}, \mathrm{In}_{2} \mathrm{O}_{3}$, $\mathrm{SnO}_{2}$, or $\mathrm{V}_{2} \mathrm{O}_{5}$ powder was ca. $0.903,19.3,37.6,41.4,2.49 \mathrm{~m}^{2} \mathrm{~g}^{-1}$, respectively. The $\mathrm{N}_{2}$ adsorption-desorption isotherms of the $\mathrm{CeO}_{2}, \mathrm{In}_{2} \mathrm{O}_{3}$, and $\mathrm{SnO}_{2}$ powders, which had relatively large SSAs, belong to "Type IV" according to the BET classification [24], because of an abrupt and quite small increase in volume of adsorbed $\mathrm{N}_{2}$ at low $P / P_{0}$ range $(\leq 0.2)$, small positive 
slope at a medium $P / P_{0}$ range and the abrupt and large increase in volume of adsorbed $\mathrm{N}_{2}$ and hysteresis at a high $P / P_{0}$ range. The hysteresis behavior is associated with capillary condensation and evaporation of $\mathrm{N}_{2}$ in and from their well-developed ink-bottle mesopores, respectively, and thus these powders showed relatively large SSAs. Besides, the size of mesopores of the $\mathrm{In}_{2} \mathrm{O}_{3}$ powder was the largest, followed by those of the $\mathrm{SnO}_{2}$ and $\mathrm{CeO}_{2}$ powders. On the other hand, the $\mathrm{N}_{2}$ adsorption-desorption isotherms of the $\mathrm{Bi}_{2} \mathrm{O}_{3}$ and $\mathrm{V}_{2} \mathrm{O}_{5}$ powders, which had quite small SSAs, basically belong to "Type II" [24], and thus the number of pore volumes of their mesopores were extremely small. However, the dependence of CS on the kinds of MO was not necessarily correspondent on that of SSA. Therefore, the geometric surface areas (GSAs) of the MO powders were calculated from CSs obtained from their XRD spectra (Fig. S1) and their densities $\left(8.90,7.22,7.18,6.95\right.$, and $3.36 \mathrm{~g} \mathrm{~cm}^{-3}$ for $\mathrm{Bi}_{2} \mathrm{O}_{3}, \mathrm{CeO}_{2}$, $\mathrm{In}_{2} \mathrm{O}_{3}, \mathrm{SnO}_{2}$, and $\mathrm{V}_{2} \mathrm{O}_{5}$, respectively [25]), assuming that the morphology of their crystallites is spherical, and the relationship between two kinds of surface areas (SSA and GSA) and CS of all the MO powders is shown in Fig. S3. The ratios of GSA to SSA (GSA/SSA values) of the $\mathrm{CeO}_{2}, \mathrm{In}_{2} \mathrm{O}_{3}$, and $\mathrm{SnO}_{2}$ powders with relatively large SSAs were quite small, which indicated that many voids among their meso-sized crystallites were the origins of well-developed inkbottle mesopores. Especially, the smallest GSA/SSA value of the $\operatorname{In}_{2} \mathrm{O}_{3}$ powder (ca. 1.1) showed that most all of the crystallites did not strongly agglomerate each other and thus gaseous species was easily able to access to the most surface and boundary of the crystallites. On the other hand, the $\mathrm{Bi}_{2} \mathrm{O}_{3}$ and $\mathrm{V}_{2} \mathrm{O}_{5}$ powders showed quite large GSA/SSA values as well as small SSAs. This means that most of their large crystallites agglomerated each other and there were little voids forming mesopores.

Figures 2 and 3 show response transients of all $\mathrm{EC}(\mathrm{MO}), \mathrm{EC}(\mathrm{Au} / \mathrm{MO})$, and $\mathrm{EC}(\mathrm{Pt} / \mathrm{MO})$ sensors to $500 \mathrm{ppm} \mathrm{CO}$ and $500 \mathrm{ppm}_{2}$, respectively, at $30^{\circ} \mathrm{C}$ in wet synthetic air $(57 \% \mathrm{RH})$, and Table $\mathrm{S} 1$ summaries the magnitude of their $\mathrm{CO}$ and $\mathrm{H}_{2}$ responses and $\mathrm{CO}$ selectivity against 
$\mathrm{H}_{2}$. Among all the $\mathrm{EC}(\mathrm{MO})$ sensors, the $\mathrm{EC}\left(\mathrm{Bi}_{2} \mathrm{O}_{3}\right)$ sensor showed relatively large responses to both $\mathrm{CO}$ and $\mathrm{H}_{2}$. The magnitude of $\mathrm{CO}$ response $\left(\Delta E_{\mathrm{CO}}\right.$ : ca. $\left.30 \mathrm{mV}\right)$ was quite similar to that of $\mathrm{H}_{2}\left(\Delta E_{\mathrm{H}_{2}}\right.$ : ca. $30 \mathrm{mV}$, the largest among all the $\mathrm{EC}(\mathrm{MO})$ sensors $)$, which indicated that the $\mathrm{EC}\left(\mathrm{Bi}_{2} \mathrm{O}_{3}\right)$ had no $\mathrm{CO}$ selectivity against $\mathrm{H}_{2}\left(\Delta E_{\mathrm{CO}} / \Delta E_{\mathrm{H}_{2}}\right.$ : ca. 1.0). Considering the large $\mathrm{CS}$, small SSA, and undeveloped pore-size distribution (small pore volume) of the $\mathrm{Bi}_{2} \mathrm{O}_{3}$ powder, the responses to both $\mathrm{CO}$ and $\mathrm{H}_{2}$ of $\mathrm{EC}\left(\mathrm{Bi}_{2} \mathrm{O}_{3}\right)$ sensor may arise only from the relatively large electrocatalytic activity of $\mathrm{CO}$ and $\mathrm{H}_{2}$ oxidation over $\mathrm{Bi}_{2} \mathrm{O}_{3}$ even at lower temperatures. However, the loading of $\mathrm{Au}$ or $\mathrm{Pt}$ onto $\mathrm{Bi}_{2} \mathrm{O}_{3}$ slightly increased the electromotive force $(E)$ of the $\mathrm{EC}\left(\mathrm{Bi}_{2} \mathrm{O}_{3}\right)$ sensor in synthetic air, only slightly increased or decreased the magnitude of both $\mathrm{CO}$ or $\mathrm{H}_{2}$ responses, respectively, and hardly improved the response and recovery speeds as well as the $\mathrm{CO}$ selectivity against $\mathrm{H}_{2}$. Namely, the loading of $\mathrm{Au}$ or $\mathrm{Pt}$ onto $\mathrm{Bi}_{2} \mathrm{O}_{3}$ was less effective in improving the CO-sensing properties of the $\mathrm{EC}\left(\mathrm{Bi}_{2} \mathrm{O}_{3}\right)$ sensor. The $\mathrm{EC}\left(\mathrm{CeO}_{2}\right)$ sensor showed the largest $\mathrm{CO}$ response $\left(\Delta E_{\mathrm{CO}}\right.$ : ca. $\left.33 \mathrm{mV}\right)$ among all the $\mathrm{EC}(\mathrm{MO})$ sensors, probably because of the relatively large electrocatalytic activity of $\mathrm{CO}$ oxidation over $\mathrm{CeO}_{2}$ [26]. However, the response and recovery speeds of the $\mathrm{EC}\left(\mathrm{CeO}_{2}\right)$ sensor were much slower than those of the $\mathrm{EC}\left(\mathrm{Bi}_{2} \mathrm{O}_{3}\right)$ sensor. The magnitude of $\mathrm{H}_{2}$ response was quite small $\left(\Delta \mathrm{E}_{\mathrm{H}_{2}}\right.$ : ca. 3 $\mathrm{mV})$, and thus the sensor showed the largest $\mathrm{CO}$ selectivity against $\mathrm{H}_{2}\left(\Delta E_{\mathrm{CO}} / \Delta E_{\mathrm{H}_{2}}:\right.$ ca. 11$)$ among all the $\mathrm{EC}(\mathrm{MO})$ sensors. The Au loading onto the $\mathrm{CeO}_{2}$ slightly improved the magnitude of $\mathrm{CO}$ response $\left(\Delta E_{\mathrm{CO}}\right.$ : ca. $\left.36 \mathrm{mV}\right)$ and moderately enhanced the magnitude of $\mathrm{H}_{2}$ response $\left(\Delta E_{\mathrm{H}_{2}}\right.$ : ca. $\left.17 \mathrm{mV}\right)$, and thus decreased the $\mathrm{CO}$ selectivity against $\mathrm{H}_{2}\left(\Delta E_{\mathrm{CO}} / \Delta E_{\mathrm{H}_{2}}\right.$ : ca. 1.9). However, the Pt loading was ineffective in improving the sensing behavior to $\mathrm{CO}$ and $\mathrm{H}_{2}$. The $\mathrm{EC}\left(\mathrm{V}_{2} \mathrm{O}_{5}\right)$ sensor showed no $\mathrm{CO}$ and $\mathrm{H}_{2}$ responses and the loading of $\mathrm{Au}$ or Pt onto the $\mathrm{V}_{2} \mathrm{O}_{5}$ did not improve the sensing behavior to $\mathrm{CO}$ and $\mathrm{H}_{2}$ at all. In addition, the electromotive force of some $\mathrm{EC}(\mathrm{MO})$ and $\mathrm{EC}(\mathrm{N} / \mathrm{MO})$ sensors in base gas (especially, $\mathrm{MO}: \mathrm{CeO}_{2}$ and $\mathrm{V}_{2} \mathrm{O}_{5}$ ) often shifted irregularly and unsteadily, due to the quite large resistance of $\mathrm{CeO}_{2}$ and $\mathrm{V}_{2} \mathrm{O}_{5}$ at $30^{\circ} \mathrm{C}$. 
On the other hand, both the $\mathrm{EC}\left(\mathrm{In}_{2} \mathrm{O}_{3}\right)$ and $\mathrm{EC}\left(\mathrm{SnO}_{2}\right)$ sensors hardly showed $\mathrm{CO}$ and $\mathrm{H}_{2}$ responses, but the loading of $\mathrm{Au}$ or Pt onto both $\mathrm{In}_{2} \mathrm{O}_{3}$ and $\mathrm{SnO}_{2}$ drastically improved the $\mathrm{CO}$ and/or $\mathrm{H}_{2}$ responses in some cases. The Au loading onto $\mathrm{In}_{2} \mathrm{O}_{3}$ and $\mathrm{SnO}_{2}$ largely improved the $\mathrm{CO}$ responses of the $\mathrm{EC}\left(\mathrm{In}_{2} \mathrm{O}_{3}\right)$ and $\mathrm{EC}\left(\mathrm{SnO}_{2}\right)$ sensors $\left(\Delta E \mathrm{EO}\right.$ : ca. $90 \mathrm{mV}$ for the $\mathrm{EC}\left(\mathrm{Au} / \mathrm{In}_{2} \mathrm{O}_{3}\right)$ sensor, ca. $100 \mathrm{mV}$ for the $\mathrm{EC}\left(\mathrm{Au} / \mathrm{SnO}_{2}\right)$ sensor $)$, respectively, with the slight overshooting behavior $[17,18]$. However, the $\mathrm{CO}$ selectivity of the $\mathrm{EC}\left(\mathrm{Au} / \mathrm{In}_{2} \mathrm{O}_{3}\right)$ and $\mathrm{EC}\left(\mathrm{Au} / \mathrm{SnO}_{2}\right)$ sensors against $\mathrm{H}_{2}\left(\Delta E_{\mathrm{CO}} / \Delta E_{\mathrm{H}_{2}}\right.$ : ca. 2.4 and ca. 2.3 , respectively) was much smaller than we had expected, because the magnitude of $\mathrm{H}_{2}$ response of the $\mathrm{EC}\left(\mathrm{Au} / \mathrm{In}_{2} \mathrm{O}_{3}\right)$ and $\mathrm{EC}\left(\mathrm{Au} / \mathrm{SnO}_{2}\right)$ sensors was also moderately large $\left(\Delta E_{\mathrm{H}_{2}}\right.$ : ca. $37 \mathrm{mV}$ and ca. $44 \mathrm{mV}$, respectively). Meanwhile, the Pt loading onto $\mathrm{In}_{2} \mathrm{O}_{3}$ was hardly effective in improving the $\mathrm{CO}$-sensing properties. However, the Pt loading onto $\mathrm{SnO}_{2}$ drastically enhanced the magnitude of $\mathrm{CO}$ response $\left(\Delta E_{\mathrm{CO}}\right.$ : ca. $\left.120 \mathrm{mV}\right)$, and the $\mathrm{CO}$ selectivity of the $\mathrm{EC}\left(\mathrm{Pt} / \mathrm{SnO}_{2}\right)$ sensor against $\mathrm{H}_{2}$ was quite large $\left(\Delta E_{\mathrm{CO}} / \Delta E_{\mathrm{H}_{2}}\right.$ : ca. 10), since the magnitude of $\mathrm{H}_{2}$ response was quite small $\left(\Delta E_{\mathrm{H}_{2}}\right.$ : ca. $\left.12 \mathrm{mV}\right)$. It is interesting to note that the response and recovery speeds of the $\mathrm{EC}\left(\mathrm{Pt} / \mathrm{SnO}_{2}\right)$ sensor to $\mathrm{CO}$ was slower than those of the $\mathrm{EC}\left(\mathrm{Au} / \mathrm{SnO}_{2}\right)$ sensor.

\subsection{Sensing mechanism of EC(N/MO) sensors to $\mathrm{CO}$ and $\mathrm{H}_{2}$}

XPS analyses of representative N/MO powders (N: Au or Pt, MO: $\mathrm{Bi}_{2} \mathrm{O}_{3}, \mathrm{In}_{2} \mathrm{O}_{3}, \mathrm{SnO}_{2}$ ) were conducted in order to clarify the effects of the loading of Au or Pt on the CO-sensing properties of the EC(N/MO) sensors. Figures 4,5 , and 6 show their XPS spectra of $\mathrm{N}$ (Au and Pt) $4 \mathrm{f}_{7 / 2}$ and $4 f_{5 / 2}, M\left(B i 4 f_{7 / 2}, \operatorname{In} 4 f_{7 / 2}\right.$, and $\left.S n 3 d_{5 / 2}\right)$, and $O 1 s$, respectively. Most of Au atoms of these $\mathrm{Au} / \mathrm{MO}$ powders existed as a metal. However, the binding energy of $\mathrm{Au}$ of $\mathrm{Au} / \mathrm{Bi}_{2} \mathrm{O}_{3}$ was the largest among them, and the binding energy of $\mathrm{Au}$ of $\mathrm{Au} / \mathrm{In}_{2} \mathrm{O}_{3}$ was slightly smaller than that of $\mathrm{Au} / \mathrm{SnO}_{2}$. This indicates that the electron density of $\mathrm{Au}$ particles loaded on the surface of $\mathrm{Au} / \mathrm{In}_{2} \mathrm{O}_{3}$ was the largest, followed by those of $\mathrm{Au} / \mathrm{SnO}_{2}$ and $\mathrm{Au} / \mathrm{Bi}_{2} \mathrm{O}_{3}$. On the other hand, most 
of Pt atoms of these $\mathrm{Pt} / \mathrm{MO}$ powders were basically oxidized, and the oxidation state was largely dependent on the kinds of the oxides. $\mathrm{Pt}$ of $\mathrm{Pt} / \mathrm{SnO}_{2}$ was most oxidized among them, and the $\mathrm{Pt} / \mathrm{SnO}_{2}$ had a large amount of $\mathrm{Pt}^{4+}$ and a medium amount of $\mathrm{Pt}^{2+}$, together with a quite small amount of Pt metal. Hübner et al. [27] and Murata et al. [28] have investigated the composition and chemical state of thick $\mathrm{Pt} / \mathrm{SnO}_{2}$ films which were fabricated by screen printing and thin Pt$\mathrm{SnO}_{2}$ composite films which were fabricated with magnetron sputtering using a $\mathrm{Pt} / \mathrm{SnO}_{2}$ target, respectively, and they have suggested that the relatively large amount of Pt was doped into the $\mathrm{SnO}_{2}$ lattice and the $\mathrm{Pt}^{\mathrm{n}+}$ species (the doping amount: $\leq$ ca. 10 at $\%$, according to the results by Murata et al. [28]) were located at the Sn position in the rutile structure. Considering the analyses of the $\mathrm{Pt}-\mathrm{SnO}_{2}$ composite films with $\mathrm{X}$-ray adsorption fine structure (XAFS) spectroscopy and XPS by Murata et al., the preparation technique of the $\mathrm{Pt} / \mathrm{SnO}_{2}$ powder in this study, and the radii of 6-coordinate ions $\left(\mathrm{Pt}^{4+}: 0.625 \AA, \mathrm{Pt}^{2+}: 0.80 \AA, \mathrm{Sn}^{4+}: 0.83 \AA[29]\right)$, it was expected that most of $\mathrm{Pt}^{4+}$ and $\mathrm{Pt}^{2+}$ were doped into the $\mathrm{Sn}^{4+}$ sites in the lattice at the $\mathrm{SnO}_{2}$ surface and a slight number of Pt-based nanoparticles, which had oxidized surface such as PtO and/or $\mathrm{PtO}_{2}$, were loaded onto the $\mathrm{SnO}_{2}$ surface. On the other hand, the main peaks of both $\mathrm{Pt} / \mathrm{Bi}_{2} \mathrm{O}_{3}$ and $\mathrm{Pt} / \mathrm{In}_{2} \mathrm{O}_{3}$ originated from $\mathrm{Pt}^{2+}$, and the ratio of the amount of $\mathrm{Pt}^{2+}$ to the amount of $\mathrm{Pt}^{4+}$ of $\mathrm{Pt} / \mathrm{Bi}_{2} \mathrm{O}_{3}$ seemed to be larger than that of $\mathrm{Pt} / \mathrm{In}_{2} \mathrm{O}_{3}$. Since the radii of 6 -coordinate $\mathrm{Bi}^{3+}$ and $\mathrm{In}^{3+}$ species $\left(\mathrm{Bi}^{3+}: 1.03 \AA, \mathrm{In}^{3+}: 0.800 \AA[29]\right)$ are larger than that of 6-coordinate $\mathrm{Pt}^{4+}$ and $\mathrm{Pt}^{2+}$ species, both the $\mathrm{Pt}^{4+}$ and $\mathrm{Pt}^{2+}$ species can be doped also into the $\mathrm{Bi}^{3+}$ and $\mathrm{In}^{3+}$ sites in the lattice at the $\mathrm{Bi}_{2} \mathrm{O}_{3}$ and $\mathrm{In}_{2} \mathrm{O}_{3}$ surfaces, respectively. As the small peak of Pt metal was also clearly confirmed in the XPS spectra of both $\mathrm{Pt} / \mathrm{In}_{2} \mathrm{O}_{3}$ and $\mathrm{Pt} / \mathrm{Bi}_{2} \mathrm{O}_{3}$, a small number of Pt metal nanoparticles were loaded on both the surfaces and the surface of the Pt metal nanoparticles may be also oxidized to be $\mathrm{PtO}$ and $\mathrm{PtO}_{2}$. Besides, the electron density of all the $\mathrm{Pt}$ species on the surface of $\mathrm{Pt} / \mathrm{SnO}_{2}$ was the largest, followed by those of $\mathrm{Pt} / \mathrm{In}_{2} \mathrm{O}_{3}$ and $\mathrm{Pt} / \mathrm{Bi}_{2} \mathrm{O}_{3}$, according to their binding energies. 
On the other hand, the binding energy of $\mathrm{Bi} 4 \mathrm{f}$ of $\mathrm{N} / \mathrm{Bi}_{2} \mathrm{O}_{3}$ was independent of the kind of $\mathrm{N}$ and the binding energy of $\mathrm{Sn} 3 \mathrm{~d}$ of $\mathrm{Pt} / \mathrm{SnO}_{2}$ was slightly larger than that of $\mathrm{Au} / \mathrm{SnO}_{2}$, while the binding energy of $\mathrm{In} 4 \mathrm{f}$ of $\mathrm{Pt} / \mathrm{In}_{2} \mathrm{O}_{3}$ was much larger than that of $\mathrm{Au} / \mathrm{In}_{2} \mathrm{O}_{3}$ (namely, the electron density of $\mathrm{In}^{3+}: \mathrm{Au} / \mathrm{In}_{2} \mathrm{O}_{3}>\mathrm{Pt} / \mathrm{In}_{2} \mathrm{O}_{3}$ ), as shown in Fig. 5. In the $\mathrm{O}$ 1s spectra, a large peak derived from lattice oxygen species and a small peak derived from adsorbed oxygen species and/or hydroxyl group were confirmed as shown in Fig. 6. In addition, their binding energies $\left(\mathrm{N} / \mathrm{Bi}_{2} \mathrm{O}_{3}<\mathrm{N} / \mathrm{In}_{2} \mathrm{O}_{3}<\mathrm{N} / \mathrm{SnO}_{2}\right.$ ) are also dependent on the kinds of oxides (namely, the electron density: $\left.\mathrm{N} / \mathrm{Bi}_{2} \mathrm{O}_{3}>\mathrm{N} / \mathrm{In}_{2} \mathrm{O}_{3}>\mathrm{N} / \mathrm{SnO}_{2}\right)$. The kind of noble metal $(\mathrm{N}, \mathrm{Au}$ or Pt) had no effect on the spectra of $\mathrm{N} / \mathrm{Bi}_{2} \mathrm{O}_{3}$ and $\mathrm{N} / \mathrm{SnO}_{2}$, while the binding energy of $\mathrm{Pt} / \mathrm{In}_{2} \mathrm{O}_{3}$ was larger than that of $\mathrm{Au} / \mathrm{In}_{2} \mathrm{O}_{3}$.

On the basis of sensing properties to $\mathrm{CO}$ and $\mathrm{H}_{2}$ and surface analyses by XPS, the gas-sensing mechanism was discussed as follows. Our previous studies have already demonstrated that the mixed potential resulting from electrochemical oxygen reduction (eq. (1)) and electrochemical CO oxidation (eq. (2)) generally determines the sensing-electrode potential of the potentiometric gas sensors in CO balanced with wet synthetic air [21, 22].

$$
\begin{aligned}
& (1 / 2) \mathrm{O}_{2}+\mathrm{H}_{2} \mathrm{O}+2 \mathrm{e}^{-} \rightarrow 2 \mathrm{OH}^{-} \\
& \mathrm{CO}+2 \mathrm{OH}^{-} \rightarrow \mathrm{CO}_{2}+\mathrm{H}_{2} \mathrm{O}+2 \mathrm{e}^{-}
\end{aligned}
$$

Actually, the relationship between the magnitude of $\mathrm{CO}$ response and the concentration in synthetic air was quite linear [21, 22]. The Au loading largely improved both the CO responses of only the $\mathrm{EC}\left(\mathrm{In}_{2} \mathrm{O}_{3}\right)$ and $\mathrm{EC}\left(\mathrm{SnO}_{2}\right)$ sensors among all the $\mathrm{EC}(\mathrm{MO})$ sensors and the magnitude of these $\mathrm{CO}$ responses was much larger than that of these $\mathrm{H}_{2}$ responses, as shown in Figs. 2 and 3. In addition, we have already reported that the Au species was uniformly loaded as nano-sized particles on the surface of $\operatorname{In}_{2} \mathrm{O}_{3}$ and $\mathrm{SnO}_{2}$ powders [21, 22], and the XPS analyses (Fig. 4) showed that the electron density of $\mathrm{Au}$ nanoparticles loaded on the $\mathrm{Au} / \mathrm{In}_{2} \mathrm{O}_{3}$ and $\mathrm{Au} / \mathrm{SnO}_{2}$ surfaces was larger than that of $\mathrm{Au}$ nanoparticles loaded on the $\mathrm{Au} / \mathrm{Bi}_{2} \mathrm{O}_{3}$ surface. $\mathrm{CO}$ molecules 
are well known to be adsorbed on the step, edge, and corner sites of Au nanoparticles as well as $\mathrm{Au} / \mathrm{MO}$ interfaces, while $\mathrm{O}_{2}$ molecules are activated at the $\mathrm{Au} / \mathrm{MO}$ interfaces by the reaction with water molecules. Thereafter, these $\mathrm{CO}$ adsorbates reacted with the activated oxygen species at the $\mathrm{Au} / \mathrm{MO}$ interfaces, to form $\mathrm{CO}_{2}[30-32]$. Based on this mechanism of catalytic $\mathrm{CO}$ oxidation under gaseous atmosphere, $\mathrm{CO}$ molecules should be adsorbed on $\mathrm{Au}$ nanoparticles on the surface of $\mathrm{In}_{2} \mathrm{O}_{3}$ and $\mathrm{SnO}_{2}$, also in this study. In addition, it was also confirmed that the binding energies of $\mathrm{In} 4 \mathrm{f}$ and $\mathrm{O} 1 \mathrm{~s}$ of $\mathrm{Au} / \mathrm{In}_{2} \mathrm{O}_{3}$ were smaller than those of $\mathrm{Pt} / \mathrm{In}_{2} \mathrm{O}_{3}$ (namely, electron density of $\mathrm{In}^{3+}$ and $\mathrm{O}^{2-}$ of $\mathrm{Au} / \mathrm{In}_{2} \mathrm{O}_{3}$ was larger than that of $\mathrm{Pt} / \mathrm{In}_{2} \mathrm{O}_{3}$.). These results indicate that the loading of Au nanoparticles partially and slightly reduced the surface of $\mathrm{In}_{2} \mathrm{O}_{3}$ and $\mathrm{SnO}_{2}$ and/or formed oxygen vacancies at the surface in some cases, especially around the $\mathrm{Au} / \mathrm{MO}$ interfaces. Therefore, the $\mathrm{Au} / \mathrm{MO}$ interfaces worked as electrochemically active redox sites, where the oxidation of the large number of $\mathrm{CO}$ adsorbates on the surface of $\mathrm{Au}$ and the $\mathrm{Au} / \mathrm{MO}$ interfaces and the reduction of oxygen adsorbates simultaneously proceeded.

$\mathrm{H}_{2}$ molecules are electrochemically oxidized in alkaline media, as shown below.

$$
\mathrm{H}_{2}+2 \mathrm{OH}^{-} \rightarrow 2 \mathrm{H}_{2} \mathrm{O}+2 \mathrm{e}^{-}
$$

It was already reported that the rate of dissociative adsorption of $\mathrm{H}_{2}$ molecules is quite slow on the surface of Au nanoparticles [33] and the dissociation mainly proceeds at $\mathrm{Au} / \mathrm{MO}$ interfaces, together with adsorption and activation of oxygen molecules at the same sites [34]. Actually, the $\mathrm{Au}$ loading improved the $\mathrm{H}_{2}$ responses of the $\mathrm{EC}\left(\mathrm{In}_{2} \mathrm{O}_{3}\right)$ and $\mathrm{EC}\left(\mathrm{SnO}_{2}\right)$ sensors. Therefore, the $\mathrm{Au} / \mathrm{MO}$ interfaces must work as electrochemically oxidation sites for adsorbed hydrogen species, also in this study. However, the magnitude of these $\mathrm{H}_{2}$ responses was smaller than that of these CO responses, as shown in Figs. 2 and 3, probably because the number of hydrogen adsorbates at the $\mathrm{Au} / \mathrm{MO}$ interfaces was much smaller than that of $\mathrm{CO}$ adsorbates on the $\mathrm{Au}$ surface as well as at the $\mathrm{Au} / \mathrm{MO}$ interfaces. 
On the other hand, the $\mathrm{EC}\left(\mathrm{Bi}_{2} \mathrm{O}_{3}\right)$ sensor showed the largest $\mathrm{CO}$ and $\mathrm{H}_{2}$ responses among all the $\mathrm{EC}(\mathrm{MO})$ sensors. The $\mathrm{Bi}_{2} \mathrm{O}_{3}$, which has some oxygen vacancies in the lattice [35], has been applied as a component of various oxidation catalysts to organic molecules [36], $\mathrm{CO}$ [37], and $\mathrm{H}_{2} \mathrm{~S}$ [38]. We also have reported that the $\mathrm{Bi}_{2} \mathrm{O}_{3}$ addition into Pt electrode largely enhanced the CO-sensing properties of NASICON-based solid electrolyte gas sensors at RT [39]. These properties support that the electrochemical oxidation activity of both $\mathrm{CO}$ and $\mathrm{H}_{2}$ are relatively active over the $\mathrm{Bi}_{2} \mathrm{O}_{3}$ surface (e.g., via oxygen vacancy [40]). However, the Au loading was ineffective in improving the $\mathrm{CO}$ and $\mathrm{H}_{2}$ responses of the $\mathrm{EC}\left(\mathrm{Bi}_{2} \mathrm{O}_{3}\right)$ sensor. Fig. 4(a)(i) showed that electron density of $\mathrm{Au}$ nanoparticles on the $\mathrm{Bi}_{2} \mathrm{O}_{3}$ surface was smaller than that on $\mathrm{In}_{2} \mathrm{O}_{3}$ and $\mathrm{SnO}_{2}$. This result shows that the chemical and electrical interaction is really small between $\mathrm{Au}$ and $\mathrm{Bi}_{2} \mathrm{O}_{3}$. Therefore, the number of $\mathrm{CO}$ adsorbates and dissociatively adsorbed hydrogen species as well as the number of activated oxygen adsorbates was quite small at $\mathrm{Au} / \mathrm{Bi}_{2} \mathrm{O}_{3}$ interfaces, and the $\mathrm{CO}$ molecules adsorbed on the Au surface were not also effectively oxidized at the $\mathrm{Au} / \mathrm{Bi}_{2} \mathrm{O}_{3}$ interfaces. The inactive $\mathrm{Au} / \mathrm{Bi}_{2} \mathrm{O}_{3}$ interfaces are probably the most important key in eliminating the effect of the Au loading on the $\mathrm{CO}$ and $\mathrm{H}_{2}$ responses of the $\mathrm{EC}\left(\mathrm{Bi}_{2} \mathrm{O}_{3}\right)$ sensor.

The Pt loading onto $\mathrm{SnO}_{2}$ drastically improved the $\mathrm{EC}\left(\mathrm{SnO}_{2}\right)$ sensor as shown in Fig. 3, while Fig. 4(b) showed that most of $\mathrm{Pt}$ was oxidized at the $\mathrm{Pt} / \mathrm{SnO}_{2}$ surface (main and sub chemical states: $\mathrm{Pt}^{4+}$ and $\mathrm{Pt}^{2+}$, respectively) and these oxidized $\mathrm{Pt}$ species were expected to be doped into the $\mathrm{Sn}^{4+}$ sites in the lattice at the $\mathrm{SnO}_{2}$ surface $[27,28]$. On the other hand, the $\mathrm{Pt}$ loading onto $\mathrm{Bi}_{2} \mathrm{O}_{3}$ and $\mathrm{In}_{2} \mathrm{O}_{3}$ was ineffective in improving the $\mathrm{EC}\left(\mathrm{Bi}_{2} \mathrm{O}_{3}\right)$ and $\mathrm{EC}\left(\mathrm{In}_{2} \mathrm{O}_{3}\right)$ sensors, respectively, as shown in Figs. 2 and 3, while Fig. 4(b) showed that most of Pt existed mainly as $\mathrm{Pt}^{2+}$ species at both the $\mathrm{Pt} / \mathrm{Bi}_{2} \mathrm{O}_{3}$ and $\mathrm{Pt} / \mathrm{In}_{2} \mathrm{O}_{3}$ surfaces and they were also expected to be doped into the $\mathrm{Sn}^{4+}$ sites in the lattice at the $\mathrm{SnO}_{2}$ surface. In addition, the fact that electron density of all the $\mathrm{Pt}$ species of $\mathrm{Pt} / \mathrm{SnO}_{2}$ was larger than those of $\mathrm{Pt} / \mathrm{Bi}_{2} \mathrm{O}_{3}$ and $\mathrm{Pt} / \mathrm{In}_{2} \mathrm{O}_{3}$ (see Fig. 
4(b)) indicates that $\mathrm{Pt} / \mathrm{SnO}_{2}$ has the relatively large number of oxygen vacancies near Pt species in the surface lattice. Moreover, CO molecules can be directly adsorbed on the active sites, while $\mathrm{H}_{2}$ molecules should be dissociatively adsorbed on the active sites. Considering these results and discussion, $\mathrm{CO}$ molecules were adsorbed just on the top of $\mathrm{Pt}^{4+}$ and/or via oxygen vacancies next to $\mathrm{Pt}^{4+}$ at the surface lattice of $\mathrm{SnO}_{2}$, and then the $\mathrm{CO}$ adsorbates electrochemically reacted with adjacent $\mathrm{OH}^{-}$adsorbates, to form $\mathrm{CO}_{2} . \mathrm{O}_{2}$ molecules also were adsorbed at the same electrochemically active sites, and then they were reduced, to form $\mathrm{OH}^{-}$. However, $\mathrm{H}_{2}$ molecules, which need to be dissociatively adsorbed on the active sites, are difficult to be adsorbed just on the individually (singly) dispersed $\mathrm{Pt}^{4+}$ sites at the surface lattice. Therefore, the $\mathrm{EC}\left(\mathrm{Pt} / \mathrm{SnO}_{2}\right)$ sensor showed only the quite small $\mathrm{H}_{2}$ response.

\subsection{Sensing properties of $\mathrm{EC}(\mathrm{N})$ sensors $(\mathrm{N}$ : $\mathrm{Au}$ or $\mathrm{Pt})$ to $\mathrm{CO}$ and $\mathrm{H}_{2}$}

In order to remove the effect of the base oxide materials (MO) on the sensing properties to both $\mathrm{CO}$ and $\mathrm{H}_{2}$, response transients of $\mathrm{EC}(\mathrm{Au})$ and $\mathrm{EC}(\mathrm{Pt})$ sensors to $500 \mathrm{ppm} \mathrm{CO}$ and $\mathrm{H}_{2}$ were investigated at $30^{\circ} \mathrm{C}$ in wet synthetic air $(57 \% \mathrm{RH})$, as shown in Fig. 7. The magnitude of their $\mathrm{CO}$ and $\mathrm{H}_{2}$ responses and $\mathrm{CO}$ selectivity against $\mathrm{H}_{2}$ were summarized in Table S2. The magnitude of $\mathrm{CO}$ and $\mathrm{H}_{2}$ responses of the $\mathrm{EC}(\mathrm{Au})$ sensor $\left(\Delta E_{\mathrm{CO}}\right.$ : ca. $38 \mathrm{mV}, \Delta E_{\mathrm{H}_{2}}$ : ca. $\left.30 \mathrm{mV}\right)$ was larger than that of the $\mathrm{EC}(\mathrm{Pt})$ sensor $\left(\Delta E_{\mathrm{CO}}\right.$ : ca. $7.2 \mathrm{mV}, \Delta E_{\mathrm{H}_{2}}$ : ca. $\left.8.8 \mathrm{mV}\right)$, and both the sensors showed poor $\mathrm{CO}$ selectivity against $\mathrm{H}_{2}\left(\Delta E_{\mathrm{CO}} / \Delta E_{\mathrm{H}_{2}}\right.$ : ca. 1.3 for the $\mathrm{EC}(\mathrm{Au})$ sensor and ca. 0.82 for the $\mathrm{EC}(\mathrm{Pt})$ sensor $)$, which was much smaller than those of the $\mathrm{EC}\left(\mathrm{Pt} / \mathrm{SnO}_{2}\right)$ sensor as well as the $\mathrm{EC}\left(\mathrm{Au} / \mathrm{SnO}_{2}\right)$ sensor. For both the $\mathrm{EC}(\mathrm{Au})$ and $\mathrm{EC}(\mathrm{Pt})$ sensors, the electrochemical oxidation of $\mathrm{CO}$ (eq. (1)) and $\mathrm{H}_{2}$ (eq. (3)) and the electrochemical reduction of $\mathrm{O}_{2}$ (eq. (2)) at the $\mathrm{Au}$ and $\mathrm{Pt}$ sensing electrodes are expected to proceed at triple-phase boundaries consisting of gas, liquid (ACP membrane), and solid ( $\mathrm{Au}$ and $\mathrm{Pt}$ ). In addition, it is well known that the exchange current density of oxygen reduction at a Au electrode is much 
smaller than that at a Pt electrode [41]. Therefore, the larger responses of the EC(Au) sensor to $\mathrm{CO}$ and $\mathrm{H}_{2}$ than those of the $\mathrm{EC}(\mathrm{Pt})$ sensor and the quite poor $\mathrm{CO}$ selectivity of both the sensors against $\mathrm{H}_{2}$ are because the electrochemical oxidation rate of $\mathrm{CO}$ at such triple-phase boundaries was relatively comparable to that of $\mathrm{H}_{2}$ and the electrochemical reduction rate of $\mathrm{O}_{2}$ at triplephase boundaries of the Au electrode is generally much smaller than that of the Pt electrode. On the other hand, both the $\mathrm{CO}$ responses of the $\mathrm{EC}(\mathrm{Au} / \mathrm{MO})$ sensor $\left(\mathrm{MO}: \operatorname{In}_{2} \mathrm{O}_{3}\right.$ or $\left.\mathrm{SnO}_{2}\right)$ and the $\mathrm{EC}\left(\mathrm{Pt} / \mathrm{SnO}_{2}\right)$ sensor were much larger than those of the $\mathrm{EC}(\mathrm{Au})$ and $\mathrm{EC}(\mathrm{Pt})$ sensors, whereas the $\mathrm{H}_{2}$ responses of the $\mathrm{EC}(\mathrm{Au} / \mathrm{MO})$ sensor $\left(\mathrm{MO}: \mathrm{In}_{2} \mathrm{O}_{3}\right.$ or $\left.\mathrm{SnO}_{2}\right)$ and the $\mathrm{EC}\left(\mathrm{Pt} / \mathrm{SnO}_{2}\right)$ sensor were comparable to those of the $\mathrm{EC}(\mathrm{Au})$ and $\mathrm{EC}(\mathrm{Pt})$ sensors, respectively. Therefore, these results indicate that the oxide surface of the $\mathrm{Au} / \mathrm{MO}\left(\mathrm{MO}: \mathrm{In}_{2} \mathrm{O}_{3}\right.$ or $\mathrm{SnO}_{2}$ ) and $\mathrm{Pt} / \mathrm{SnO}_{2}$ sensing electrodes serves a quite important function as a part of the reaction sites especially for the electrochemical $\mathrm{CO}$ oxidation, and thus the combination of the oxide surface with $\mathrm{Au}$ or $\mathrm{Pt}$ nanoparticles at these sensing electrodes enhanced only the magnitude of $\mathrm{CO}$ responses for the $\mathrm{EC}(\mathrm{Au} / \mathrm{MO})$ sensor $\left(\mathrm{MO}: \mathrm{In}_{2} \mathrm{O}_{3}\right.$ or $\left.\mathrm{SnO}_{2}\right)$ and the $\mathrm{EC}\left(\mathrm{Pt} / \mathrm{SnO}_{2}\right)$ sensors.

\subsection{Sensing properties of $\mathrm{EC}\left(\mathrm{N} / \mathrm{SnO}_{2}\right)$ sensors to $\mathrm{CO}$ and $\mathrm{H}_{2}$}

Effects of the kinds of noble metal (N) loaded onto $\mathrm{SnO}_{2}$ on the sensing properties of $\mathrm{EC}\left(\mathrm{N} / \mathrm{SnO}_{2}\right)$ sensors to $\mathrm{CO}$ and $\mathrm{H}_{2}$ were also investigated in this study. Figure 8 shows response transients of all the $\mathrm{EC}\left(\mathrm{N} / \mathrm{SnO}_{2}\right)$ sensors to $500 \mathrm{ppm} \mathrm{CO}$ and $\mathrm{H}_{2}$ at $30^{\circ} \mathrm{C}$ in wet synthetic air (57\% RH). The magnitude of their $\mathrm{CO}$ and $\mathrm{H}_{2}$ responses and $\mathrm{CO}$ selectivity against $\mathrm{H}_{2}$ were summarized in Table $\mathrm{S} 3$. The $\mathrm{EC}\left(\mathrm{Au} / \mathrm{SnO}_{2}\right)$ and $\mathrm{EC}\left(\mathrm{Pt} / \mathrm{SnO}_{2}\right)$ sensors showed large $\mathrm{CO}$ responses with relatively small $\mathrm{H}_{2}$ responses, as shown in Section 3.2. On the other hand, the other $\mathrm{EC}\left(\mathrm{N} / \mathrm{SnO}_{2}\right)$ sensors $(\mathrm{N}$ : $\mathrm{Ag}, \mathrm{Ir}, \mathrm{Rh}$, and $\mathrm{Ru})$, which did not involve the $\mathrm{EC}\left(\mathrm{Pd} / \mathrm{SnO}_{2}\right)$ sensor, showed little $\mathrm{CO}$ and $\mathrm{H}_{2}$ responses. The $\mathrm{EC}\left(\mathrm{Pd} / \mathrm{SnO}_{2}\right)$ sensor unstably showed the large $\mathrm{CO}$ response $\left(\Delta E_{\mathrm{CO}}:\right.$ ca. $\left.56 \mathrm{mV}\right)$ with too large overshooting behavior. In addition, the 
electromotive force $(E)$ of the sensor in wet synthetic air (base gas) gradually tended to shift positively after exposure to $\mathrm{CO}$, and the $E$ value attained to ca. $111 \mathrm{mV}$ in wet synthetic air, before the $\mathrm{H}_{2}$-sensing property of the sensor was measured. The magnitude of $\mathrm{H}_{2}$ response of this sensor toward the $E$ value $\left(\Delta E_{\mathrm{H}_{2}}\right.$ : ca. $\left.95 \mathrm{mV}\right)$ was larger than that of the $\mathrm{CO}$ response, and thus the $\mathrm{CO}$ selectivity against $\mathrm{H}_{2}$ was quite small $\left(\Delta E_{\mathrm{CO}} / \Delta E_{\mathrm{H}_{2}}\right.$ : ca. 0.59$)$. These results indicate that the exposure to reducing gases such as $\mathrm{CO}$ and $\mathrm{H}_{2}$ in wet synthetic air changed the chemical states of $\mathrm{Pd}$ species and/or $\mathrm{SnO}_{2}$. Actually, the color of the $\mathrm{Pd} / \mathrm{SnO}_{2}$ sensing electrode largely changed from gray to black after the measurement, even though the color of the counter electrode only after exposure to a base gas (wet synthetic air) didn't change. Therefore, XPS analyses of the sensing electrodes of the $\mathrm{EC}\left(\mathrm{Pd} / \mathrm{SnO}_{2}\right)$ sensor were performed before and after exposure to 3000 ppm $\mathrm{CO}$ and $\mathrm{H}_{2}$ balanced with wet synthetic air for $2 \mathrm{~h}$, as shown in Fig. 9 and Fig. S4. XPS spectra of $\operatorname{Sn} 3 \mathrm{~d}_{5 / 2}$ and $\mathrm{O} 1 \mathrm{~s}$ of all the sensing electrodes were hardly influenced even by exposure to the highly concentrated $\mathrm{CO}$ and $\mathrm{H}_{2}$ atmospheres balanced with wet synthetic air (Fig. S4). However, the binding energies of both the XPS spectra of both the components of all the electrodes were smaller than those of the $\mathrm{Au} / \mathrm{SnO}_{2}$ and $\mathrm{Pt} / \mathrm{SnO}_{2}$ powders (see Figs. 5 and 6), because of the large number of oxygen vacancies as well as the large electron density of $\mathrm{Sn}$ and $\mathrm{O}$ species by the loading of Pd species on the $\mathrm{SnO}_{2}$ surface. On the other hand, XPS spectra of Pd 3d of the sensing electrodes was sensitive to the gaseous atmosphere. Namely, most of the $\mathrm{Pd}$ component on the $\mathrm{SnO}_{2}$ surface was $\mathrm{PdO}$ before exposure to $\mathrm{CO}$ or $\mathrm{H}_{2}$, but the exposure to $\mathrm{CO}$ or $\mathrm{H}_{2}$ surprisingly oxidized a part of the $\mathrm{PdO}$ species to form $\mathrm{PdO}_{2}$. The electrochemical oxidation of $\mathrm{CO}$ or $\mathrm{H}_{2}$ and electrochemical reduction of $\mathrm{O}_{2}$, which simultaneously proceed at the sensing electrode under the gaseous atmospheres, must have induced the oxidation from $\mathrm{PdO}$ to $\mathrm{PdO}_{2}$, but we don't have sufficient information to understand the mechanism at present. However, the change in the chemical states of the Pd species can explain a rise in the electromotive force $(E)$ of the $\mathrm{EC}\left(\mathrm{Pd} / \mathrm{SnO}_{2}\right)$ sensor with exposure to $\mathrm{CO}$ 
and $\mathrm{H}_{2}$ balanced with wet synthetic air, because the standard redox potentials of $\mathrm{Pd} / \mathrm{PdO}$ and $\mathrm{PdO} / \mathrm{PdO}_{2}$ are +0.896 and $+1.283 \mathrm{~V}$ (vs. SHE), respectively. As such increase in the electromotive force was not confirmed when carbon black was utilized as a base electrode material for the Pd loading in spite of $\mathrm{SnO}_{2}[19,20]$, the chemical properties of the $\mathrm{SnO}_{2}$ surface have a large influence on the stability of $\mathrm{PdO}$ species in $\mathrm{CO}$ or $\mathrm{H}_{2}$ balanced with wet synthetic air.

Our previous studies have demonstrated that heat treatment of the $\mathrm{Au} / \mathrm{SnO}_{2}$ powder under $\mathrm{H}_{2}$ atmosphere at $250^{\circ} \mathrm{C}$ reduced the magnitude of $\mathrm{H}_{2}$ response of the $\mathrm{EC}\left(\mathrm{Au} / \mathrm{SnO}_{2}\right)$ sensor, while maintaining the large $\mathrm{CO}$ response, and thus it drastically improved the $\mathrm{CO}$ selectivity against $\mathrm{H}_{2}$ [22]. Therefore, all the $\mathrm{N} / \mathrm{SnO}_{2}$ powders prepared in this study were also heat-treated at the same reducing condition (in $\mathrm{H}_{2}$ at $250^{\circ} \mathrm{C}$ for $2 \mathrm{~h}$ ), the effects of the heat treatment of the $\mathrm{N} / \mathrm{SnO}_{2}$ powders on the $\mathrm{CO}$-sensing properties. Figure 10 shows response transients of all the $\mathrm{EC}\left(\mathrm{N} / \mathrm{SnO}_{2}-\mathrm{h}\right)$ sensors to $500 \mathrm{ppm} \mathrm{CO}$ and $\mathrm{H}_{2}$ at $30^{\circ} \mathrm{C}$ in wet synthetic air $(57 \% \mathrm{RH})$, and Table $\mathrm{S} 3$ summarizes the magnitude of their $\mathrm{CO}$ and $\mathrm{H}_{2}$ responses and $\mathrm{CO}$ selectivity against $\mathrm{H}_{2}$. The heat treatment of the $\mathrm{Au} / \mathrm{SnO}_{2}$ powder in $\mathrm{H}_{2}$ drastically decreased the $\mathrm{H}_{2}$ response $\left(\Delta E_{\mathrm{H}_{2}}\right.$ : ca. 3 $\mathrm{mV})$, with maintaining the magnitude of $\mathrm{CO}$ response $\left(\Delta E_{\mathrm{CO}}\right.$ : ca. $\left.100 \mathrm{mV}\right)$ and thus the $\mathrm{EC}\left(\mathrm{Au} / \mathrm{SnO}_{2}-\mathrm{h}\right)$ sensor showed excellent $\mathrm{CO}$ selectivity against $\mathrm{H}_{2}\left(\Delta E_{\mathrm{CO}} / \Delta E_{\mathrm{H}_{2}}\right.$ : ca. 33$)$, also as shown in our previous report [22]. The only decrease in the $\mathrm{H}_{2}$ response may arise from a decrease in the number of dissociatively adsorbed hydrogen species at $\mathrm{Au} / \mathrm{SnO}_{2}$ interfaces. On the other hand, the $\mathrm{CO}$ and $\mathrm{H}_{2}$ responses of the $\mathrm{EC}\left(\mathrm{Pt} / \mathrm{SnO}_{2}-\mathrm{h}\right)$ sensor $\left(\Delta E_{\mathrm{CO}}\right.$ : ca. $221 \mathrm{mV}, \Delta E_{\mathrm{H}_{2}}$ : ca. $118 \mathrm{mV})$ were much larger than those of the $\mathrm{EC}\left(\mathrm{Pt} / \mathrm{SnO}_{2}\right)$ sensor $\left(\Delta E_{\mathrm{CO}}\right.$ : ca. $120 \mathrm{mV}, \Delta E_{\mathrm{H}_{2}}$ : ca. $12 \mathrm{mV}$, see Fig. 3), but thus the $\mathrm{CO}$ selectivity the $\mathrm{EC}\left(\mathrm{Pt} / \mathrm{SnO}_{2}-\mathrm{h}\right)$ sensor against $\mathrm{H}_{2}$ was quite small $\left(\Delta E_{\mathrm{CO}} / \Delta E_{\mathrm{H}_{2}}\right.$ : ca. 1.9), in comparison with that of the $\mathrm{EC}\left(\mathrm{Pt} / \mathrm{SnO}_{2}\right)$ sensor $\left(\Delta E_{\mathrm{CO}} / \Delta E_{\mathrm{H}_{2}}:\right.$ ca. 10$)$. These results indicate that the surface of Pt metal nanoparticles and/or the $\mathrm{Pt} / \mathrm{SnO}_{2}$ interfaces, which were produced by heat treatment in $\mathrm{H}_{2}$ at $250^{\circ} \mathrm{C}$ for $1 \mathrm{~h}$, worked as 
electrochemically active sites for $\mathrm{CO}$ and $\mathrm{H}_{2}$ oxidation and the electrochemical oxidation activities at these reaction sites of the $\mathrm{Pt} / \mathrm{SnO}_{2}-\mathrm{h}$ sensing electrode against $\mathrm{CO}$ and $\mathrm{H}_{2}$ were much larger than those at the $\mathrm{PtOx}$-based reaction sites of the $\mathrm{Pt} / \mathrm{SnO}_{2}$ sensing electrode. For the $\mathrm{EC}\left(\mathrm{Pd} / \mathrm{SnO}_{2}-\mathrm{h}\right)$ sensor, the electromotive force was quite stable in comparison of that of the $\mathrm{EC}\left(\mathrm{Pd} / \mathrm{SnO}_{2}\right)$ sensor, but both the $\mathrm{CO}$ and $\mathrm{H}_{2}$ responses were much smaller than those of the $\mathrm{EC}\left(\mathrm{Pd} / \mathrm{SnO}_{2}\right)$ sensor. In addition, three kinds of the $\mathrm{EC}\left(\mathrm{N} / \mathrm{SnO}_{2}-\mathrm{h}\right)$ sensors $(\mathrm{N}$ : $\mathrm{Ag}, \mathrm{Ir}$, and $\mathrm{Rh})$ hardly showed $\mathrm{CO}$ and $\mathrm{H}_{2}$ responses, as is the case with the $\mathrm{EC}\left(\mathrm{N} / \mathrm{SnO}_{2}\right)$ sensors $(\mathrm{N}$ : $\mathrm{Ag}$, $\mathrm{Ir}$, and $\mathrm{Rh}$ ). The electrochemical $\mathrm{O}_{2}$ reduction activity may be too much larger than the electrochemical $\mathrm{CO}$ and $\mathrm{H}_{2}$ oxidation activities at the reaction sites of these $\mathrm{N} / \mathrm{SnO}_{2}$ electrodes and thus these electrode potentials were not able to shift to the negative direction. Except for the $\mathrm{EC}\left(\mathrm{N} / \mathrm{SnO}_{2}-\mathrm{h}\right)$ sensors $(\mathrm{Au}$ and $\mathrm{Pt})$, only the $\mathrm{EC}\left(\mathrm{Ru} / \mathrm{SnO}_{2}-\mathrm{h}\right)$ sensor showed relatively large $\mathrm{CO}$ and $\mathrm{H}_{2}$ responses $\left(\Delta E_{\mathrm{CO}}\right.$ : ca. $40 \mathrm{mV}, \Delta E_{\mathrm{H}_{2}}$ : ca. $\left.19 \mathrm{mV}\right)$, but the $\mathrm{CO}$-sensing properties $(\mathrm{CO}$ selectivity against $\mathrm{H}_{2}\left(\Delta E_{\mathrm{CO}} / \Delta E_{\mathrm{H}_{2}}\right.$ : ca. 2.1) as well as the magnitude of the $\mathrm{CO}$ response $)$ of the $\mathrm{EC}\left(\mathrm{Ru} / \mathrm{SnO}_{2}-\mathrm{h}\right)$ sensor were far inferior to those of the $\mathrm{EC}\left(\mathrm{Au} / \mathrm{SnO}_{2}-\mathrm{h}\right)$ sensor. Hereafter, we will clarify the effects of the $\mathrm{N}$ loading onto the $\mathrm{MO}$ surface ( $\mathrm{MO}: \mathrm{SnO}_{2}$, especially) on the sensing properties of the $\mathrm{EC}(\mathrm{N} / \mathrm{MO})$ and $\mathrm{EC}(\mathrm{N} / \mathrm{MO}-\mathrm{h})$ sensors to $\mathrm{CO}$ and $\mathrm{H}_{2}$, to design highly CO sensitive and selective electrochemical gas sensors using an ACP electrolyte and oxidebased electrodes.

\section{Conclusions}

CO-sensing properties of EC(MO) and EC(N/MO) sensors were measured in wet synthetic air $(57 \% \mathrm{RH})$ at $30^{\circ} \mathrm{C}$, and effects of the kinds of $\mathrm{MO}$ as a base electrode material and $\mathrm{N}$ loaded on the MO surface on their CO-sensing properties were investigated in this study. The $\mathrm{EC}\left(\mathrm{CeO}_{2}\right)$ and $\mathrm{EC}\left(\mathrm{Bi}_{2} \mathrm{O}_{3}\right)$ sensors showed relatively large $\mathrm{CO}$ response and only the $\mathrm{EC}\left(\mathrm{Bi}_{2} \mathrm{O}_{3}\right)$ sensor responded to $\mathrm{H}_{2}$, among all the $\mathrm{EC}(\mathrm{MO})$ sensors. However, the loading of $\mathrm{Au}$ or Pt onto 
$\mathrm{CeO}_{2}$ and $\mathrm{Bi}_{2} \mathrm{O}_{3}$ was not effective in improving these sensing properties. On the other hand, the $\mathrm{EC}\left(\mathrm{In}_{2} \mathrm{O}_{3}\right)$ and $\mathrm{EC}\left(\mathrm{SnO}_{2}\right)$ sensors hardly showed both $\mathrm{CO}$ and $\mathrm{H}_{2}$ responses. However, the $\mathrm{Au}$ loading was quite effective in improving the magnitude of $\mathrm{CO}$ and $\mathrm{H}_{2}$ responses of both the $\mathrm{EC}\left(\mathrm{In}_{2} \mathrm{O}_{3}\right)$ and $\mathrm{EC}\left(\mathrm{SnO}_{2}\right)$ sensors $\left(\Delta E_{\mathrm{CO}}>\Delta E_{\mathrm{H}_{2}}\right)$. This result indicates that the oxidation of $\mathrm{CO}$ and hydrogen adsorbates and the reduction of oxygen adsorbates electrochemically proceeded at the $\mathrm{Au} / \mathrm{MO}$ interfaces and the number of $\mathrm{CO}$ adsorbates was larger than that of hydrogen adsorbates. On the other hand, the Pt loading largely enhanced the magnitude of CO response of the $\mathrm{EC}\left(\mathrm{SnO}_{2}\right)$ sensor, but was not so much effective in improving the magnitude of $\mathrm{H}_{2}$ response. Therefore, the $\mathrm{EC}\left(\mathrm{Pt} / \mathrm{SnO}_{2}\right)$ sensor showed the most excellent $\mathrm{CO}$ selectivity against $\mathrm{H}_{2}$, among all the sensors in this study. The XPS spectra of the $\mathrm{Pt} / \mathrm{SnO}_{2}$ and the sensing properties of the $\mathrm{EC}\left(\mathrm{Pt} / \mathrm{SnO}_{2}\right)$ sensor suggest that the large number of $\mathrm{CO}$ molecules was easily adsorbed on $\mathrm{Pt}^{4+}$ sites and/or via oxygen vacancies next to $\mathrm{Pt}^{4+}$ at the surface lattice of $\mathrm{SnO}_{2}$. Among other $\mathrm{EC}\left(\mathrm{N} / \mathrm{SnO}_{2}\right)$ sensors, only the $\mathrm{EC}\left(\mathrm{Pd} / \mathrm{SnO}_{2}\right)$ sensor showed large $\mathrm{CO}$ and $\mathrm{H}_{2}$ responses, together with the operating instability which was caused by the oxidation of Pdbased reaction sites. The heat treatment of N/MO powders in $\mathrm{H}_{2} 250^{\circ} \mathrm{C}$ had various impacts on their $\mathrm{CO}$ and $\mathrm{H}_{2}$ responses in some cases. Namely, the heat treatment largely reduced the $\mathrm{CO}$ and $\mathrm{H}_{2}$ responses of the $\mathrm{EC}\left(\mathrm{Pd} / \mathrm{SnO}_{2}\right)$ sensor, moderately increased the $\mathrm{CO}$ and $\mathrm{H}_{2}$ responses of the $\mathrm{EC}\left(\mathrm{Ru} / \mathrm{SnO}_{2}\right)$ sensor, improved the $\mathrm{CO}$ selectivity of the $\mathrm{EC}\left(\mathrm{Au} / \mathrm{SnO}_{2}\right)$ sensor against $\mathrm{H}_{2}$ together with a considerable decrease in the $\mathrm{H}_{2}$ response, and enhanced both $\mathrm{CO}$ and $\mathrm{H}_{2}$ responses of the $\mathrm{EC}\left(\mathrm{Pt} / \mathrm{SnO}_{2}\right)$ sensor, leading to a decrease in its $\mathrm{CO}$ selectivity against $\mathrm{H}_{2}$. 


\section{References}

[1] WHO Regional Office for Europe, Copenhagen, Denmark, Air quality guidelines for Europe, 2nd edition (CD ROM version), WHO Regional Publications, European Series, No. 91 (2000).

[2] D. Koziej, N. Bârsan, K. Shimanoe, N. Yamazoe, J. Szuber, U. Weimar, Spectroscopic insights into $\mathrm{CO}$ sensing of undoped and palladium doped tin dioxide sensors derived from hydrothermally treated tin oxide sol, Sens. Actuators B 118 (2006) 98-104.

[3] J. W. Fergus, Solid electrolyte based sensors for the measurement of CO and hydrocarbon gases, Sen. Actuators B 122 (2007) 683-693.

[4] N. Izu, I. Matsubara, T. Itoh, W. Shin, Performance of a carbon monoxide sensor based on zirconia-doped ceria, J. Asian Ceram. Soc. 4 (2016) 205-208.

[5] Y. Shimizu, S. Yamamoto, S. Takase, A thick-film impedancemetric carbon monoxide sensor using layered perovskite-type cuprate, Sens. Actuators B 249 (2017) 667-672.

[6] T. Goto, T. Itoh, T. Akamatsu, T. Sekino, W. Shin, Relationship between the CO sensing performance of micro-thermoelectric gas sensors and characteristics of $\mathrm{PtPd} / \mathrm{Co}_{3} \mathrm{O}_{4}$ and $\mathrm{PtPd} / \mathrm{SnO}_{2}$ catalysts, Sens. Actuators B 243 (2017) 847-855.

[7] N. Miura, H. Kato, H. Yamazoe, T. Seiyama, A proton conductor gas sensor operative at ordinary temperature, Denki Kagaku (presently Electrochemistry) 50 (1982) 858-859.

[8] N. Miura, H. Kato, N. Yamazoe, and T. Seiyama, An improved type of proton conductor sensor sensitive to $\mathrm{H}_{2}$ and $\mathrm{CO}$ at room temperature, Chem. Lett. 12 (1983) 1573-1576.

[9] P. D. van del Wal, N. F. de Rooij, M. Koudelka-Hep, Extremely stable Nafion based carbon monoxide sensor, Sens. Actuators B 35 (1996) 119-123.

[10] R. J. Mortimer, A. Beech, AC impedance characteristics of solid-state planar electrochemical carbon monoxide sensors with $\mathrm{Nafion}^{\circledR}$ as solid polymer electrolyte, Electrochim. Acta 47 (2002) 3383-3387. 
[11] K. Mochizuki, T. Kikuchi, M. Sudoh, Y. Ishiguro, T. Suzuki, Performances of fuel-celltype $\mathrm{CO}$ sensors using each of polybenzimidazole and Nafion membranes, J. Electrochem. Soc. 158 (2011) J71-J75.

[12] Y. Guan, M. Dai, T. Liu, Y. Liu, F. Liu, X. Liang, H. Suo, P. Sun, G. Lu, Effect of the dispersants on the performance of fuel cell type $\mathrm{CO}$ sensor with $\mathrm{Pt}-\mathrm{C} / \mathrm{Nafion}$ electrodes, Sens. Actuators B 230 (2016) 61-69.

[13] Y. Guan, F. Liu, B. Wang, X. Yang, X. Liang, H. Suo, P. Sun, Y. Sun, J. Ma, J. Zheng, Y. Wang, G. Lu, Highly sensitive amperometric Nafion-based CO sensor using Pt/C electrodes with different kinds of carbon materials, Sens. Actuators B 239 (2017) 696703.

[14] K. Izawa, Introduction of carbon monoxide gas sensors and their application, Chemical Sensors 34 (2018) 8-13.

[15] H. Yanagi, K. Fukuda, Anion exchange membrane and ionomer for alkaline membrane fuel cells (AMFCs), ECS Trans. 16(2) (2008) 257-262.

[16] K. Fukuta, H. Inoue, S. Watanabe, H. Yanagi, In-situ observation of CO2 through the selfpurging in alkaline membrane fuel cell (AMFC), ECS Trans. 19(31) (2009) 23-27.

[17] K. Matsumoto, T. Fujigaya, H. Yanagi, N. Nakashima, Very high performance alkali anion-exchange membrane fuel cells, Adv. Funct. Mater. 21 (2011) 1089-1094.

[18] T. Hyodo, C. Ishibashi, H. Yanagi, K. Kaneyasu, Y. Shimizu, Potentiometric hydrogen sensors using an anion-conducting polymer as an electrolyte, Reports of the Faculty of Engineering, Nagasaki University 42(79) (2012) 42-47.

[19] T. Goto, T. Hyodo, K. Kaneyasu, H. Yanagi, and Y. Shimizu, CO sensing properties of electrochemical gas sensors using an anion-conducting polymer as an electrolyte, ECS Trans. 50(12) (2013) 267-272.

[20] T. Hyodo, C. Ishibashi, K. Matsuo, K. Kaneyasu, H. Yanagi, Y. Shimizu, CO and $\mathrm{CO}_{2}$ 
sensing properties of electrochemical gas sensors using an anion-conducting polymer as an electrolyte, Electrochim. Acta 82 (2012) 19-25.

[21] T. Goto, T. Hyodo, T. Ueda, K. Kamada, K. Kaneyasu, Y. Shimizu, CO-sensing properties of potentiometric gas sensors using an anion-conducting polymer electrolyte and Auloaded metal oxide electrodes, Electrochim. Acta 166 (2015) 232-243.

[22] T. Hyodo, T. Goto, T. Ueda, K. Kaneyasu, Y. Shimizu, Potentiometric carbon monoxide sensors using an anion-conducting polymer electrolyte and $\mathrm{Au}$-loaded $\mathrm{SnO}_{2}$ electrodes, J. Electrochem. Soc. 163 (2016) B300-B308.

[23] L.-F. Gutierrez, S. Hamoudi, K. Belkacemi, Synthesis of gold catalysts supported on mesoporous silica materials: recent developments Catalysts 1 (2011) 97-154.

[24] K. S. W. Sing, Reporting physisorption data for gas/solid systems with special reference to the determination of surface area and porosity, Pure Appl. Chem. 54 (1982) 2201-2218.

[25] Kurt J. Lesker Co., Installation and operation manual of FTC-2800 (thin film deposition controller), Ver. 6.10 (2009).

[26] T. Ueda, H. Takeda, K. Kamada, T. Hyodo, Y. Shimizu, Enhanced CO response of NASICON-based gas sensors using oxide-added Pt sensing electrode at low temperature operation, Electrochemistry 85 (2017) 174-178.

[27] M. Hübner, D. Koziej, M. Bauer, N. Barsan, K. Kvashnina, M. D. Rossell, U. Weimar, J.D. Grunwaldt, The structure and behavior of platinum in $\mathrm{SnO}_{2}$-based sensors under working conditions, Angew. Chem. Int. Ed. 50 (2011) 2841-2844.

[28] N. Murata, T. Suzuki, M. Kobayashi, F. Togoh, K. Asakura, Characterization of Pt-doped $\mathrm{SnO}_{2}$ catalyst for a high-performance micro gas sensor, Phys. Chem. Chem. Phys. 15 (2013) 17938-17946.

[29] R. D. Shannon, Revised effective ionic radii and systematic studies of interatomic distances in halides and chalcogenides, Acta Cryst. A32 (1976) 751-767. 
[30] M. Daté, Y. Ichihashi, T. Yamashita, A. Chiorino, F. Boccuzzi, M. Haruta, Performance of $\mathrm{Au} / \mathrm{TiO}_{2}$ catalyst under ambient conditions, Catal. Today 72 (2002) 89-94.

[31] T. Fujitani, I. Nakamura, Mechanism and active sites of the oxidation of $\mathrm{CO}$ over $\mathrm{Au} / \mathrm{TiO}_{2}$, Angew. Chem. Int. Ed. 50 (2011) 10144-10147.

[32] M. Haruta, Chance and necessity: My encounter with gold catalysts, Angew. Chem. Int. Ed. 53 (2014) 52-56.

[33] B. Hammer, J. K. Norskov, Why gold is the noblest of all the metals, Nature 376 (1995) $238-241$.

[34] T. Fujitani, I. Nakamura, T. Akita, M. Okumura, M. Haruta, Hydrogen dissociation by gold clusters, Angew. Chem. Int. Ed. 48 (2009) 9515-9518.

[35] P. Torruella, C. Coll, G. Martín, L. López-Conesa, M. Vila, C. Díaz-Guerra, M. Varela, M. L. Ruiz-González, J. Piqueras, F. Peiró, S. Estradé, Assessing oxygen vacancies in bismuth oxide through EELS measurements and DFT simulations, J. Phys. Chem. C 121 (2017) 24809-24815.

[36] T. Sakamoto, M. Egashira, T. Seiyama, New catalytic aromatization of lower olefins over bismuth phosphate catalyst, J. Catal. 16 (1970) 407-409.

[37] Y. Lou, L. Wang, Z. Zhao, Y. Zhang, Z. Zhang, G. Lu, Y. Guo, Y. L. Guo, Lowtemperature $\mathrm{CO}$ oxidation over $\mathrm{Co}_{3} \mathrm{O}_{4}$-based catalysts: Significant promoting effect of $\mathrm{Bi}_{2} \mathrm{O}_{3}$ on $\mathrm{Co}_{3} \mathrm{O}_{4}$ catalyst, Appl. Catal. B 146 (2014) 43-49.

[38] Y.-G. Cho, B.-H. Hwang, D.-W. Park, H.-C. Woo, J.-S. Chung, Phase cooperation of $\mathrm{V}_{2} \mathrm{O}_{5}$ and $\mathrm{Bi}_{2} \mathrm{O}_{3}$ in the selective oxidation of $\mathrm{H}_{2} \mathrm{~S}$ containing ammonia and water, Korean $\mathrm{J}$. Chem. Eng. 19 (2002) 611-616.

[39] H. Takeda, T. Ueda, K. Kamada, K. Matsuo, T. Hyodo, Y. Shimizu, CO-sensing properties of a NASICON-based gas sensor attached with $\mathrm{Pt}$ mixed with $\mathrm{Bi}_{2} \mathrm{O}_{3}$ as a sensing electrode, Electrochem. Acta 155 (2015) 8-15. 
[40] E. N. Voskresenskaya, L. I. Kurteeva, A. G. Anshits, Solid solutions of bismuth oxide as promising catalysts for oxidative coupling of methane, Appl. Catal. A 90 (1992) 209-216.

[41] C. Song, J. Zhang, Electrocatalytic oxygen reduction reaction, in: J. Zhang (Ed.), PEM Fuel Cell Electrocatalysts and Catalyst Layers, Springer, Berlin, 2008, pp. 89-134. 


\section{Figure Captions}

Fig. 1. Schematic drawings of (a) sensor element and (b) gas-sensing measurement system with two electrode compartments.

Fig. 2. Response transients of $\mathrm{EC}(\mathrm{MO})$ and $\mathrm{EC}(\mathrm{N} / \mathrm{MO})$ sensors (MO: $\mathrm{Bi}_{2} \mathrm{O}_{3}, \mathrm{CeO}_{2}, \mathrm{In}_{2} \mathrm{O}_{3}$, $\mathrm{SnO}_{2}$, and $\mathrm{V}_{2} \mathrm{O}_{5}, \mathrm{~N}: \mathrm{Au}$ and $\left.\mathrm{Pt}\right)$ to $500 \mathrm{ppm} \mathrm{CO}$ in wet synthetic air at $30^{\circ} \mathrm{C}(57 \% \mathrm{RH})$.

Fig. 3. Response transients of $\mathrm{EC}(\mathrm{MO})$ and $\mathrm{EC}(\mathrm{N} / \mathrm{MO})$ sensors $\left(\mathrm{MO}: \mathrm{Bi}_{2} \mathrm{O}_{3}, \mathrm{CeO}_{2}, \mathrm{In}_{2} \mathrm{O}_{3}\right.$, $\mathrm{SnO}_{2}$, and $\mathrm{V}_{2} \mathrm{O}_{5}, \mathrm{~N}$ : $\mathrm{Au}$ and $\left.\mathrm{Pt}\right)$ to $500 \mathrm{ppm} \mathrm{H}_{2}$ in wet synthetic air at $30^{\circ} \mathrm{C}(57 \% \mathrm{RH})$.

Fig. 4. XPS spectra of $\mathrm{Au} 4 \mathrm{f}$ and $\mathrm{Pt} 4 \mathrm{f}$ of N/MO powders (N: Au and Pt, MO: $\mathrm{Bi}_{2} \mathrm{O}_{3}, \mathrm{In}_{2} \mathrm{O}_{3}$, and $\mathrm{SnO}_{2}$ ).

Fig. 5. XPS spectra of $\mathrm{Bi} 4 \mathrm{f}_{7 / 2}$ of $\mathrm{N} / \mathrm{Bi}_{2} \mathrm{O}_{3}$ powder, $\mathrm{In} 4 \mathrm{f}_{7 / 2}$ of $\mathrm{N} / \mathrm{In}_{2} \mathrm{O}_{3}$ powder, and $\mathrm{Sn} 3 \mathrm{~d}_{5 / 2}$ of $\mathrm{N} / \mathrm{SnO}_{2}$ powder $(\mathrm{N}$ : Au and $\mathrm{Pt})$.

Fig. 6. XPS spectra of $\mathrm{O} 1 \mathrm{~s}$ of $\mathrm{N} / \mathrm{MO}$ powders (N: $\mathrm{Au}$ and $\mathrm{Pt}, \mathrm{MO}: \mathrm{Bi}_{2} \mathrm{O}_{3}, \mathrm{In}_{2} \mathrm{O}_{3}$, and $\mathrm{SnO}_{2}$ ).

Fig. 7. Response transients of $\mathrm{EC}(\mathrm{Au})$ and $\mathrm{EC}(\mathrm{Pt})$ sensors to $500 \mathrm{ppm} \mathrm{CO}$ and $500 \mathrm{ppm} \mathrm{H}_{2}$ in wet synthetic air at $30^{\circ} \mathrm{C}(57 \% \mathrm{RH})$.

Fig. 8. Response transients of $\mathrm{EC}\left(\mathrm{N} / \mathrm{SnO}_{2}\right)$ sensors (N: Ag, $\mathrm{Au}, \mathrm{Ir}, \mathrm{Rh}, \mathrm{Ru}, \mathrm{Pd}$, and Pt) to (a) $500 \mathrm{ppm} \mathrm{CO}$ and (b) $500 \mathrm{ppm} \mathrm{H}_{2}$ in wet synthetic air at $30^{\circ} \mathrm{C}(57 \% \mathrm{RH})$.

Fig. 9. $\mathrm{XRD}$ spectra of $\mathrm{Pd} 3 \mathrm{~d}$ of $\mathrm{Pd} / \mathrm{SnO}_{2}$ sensing electrode of $\mathrm{EC}\left(\mathrm{Pd} / \mathrm{SnO}_{2}\right)$ sensor before and after exposure to 3000 ppm CO and $\mathrm{H}_{2}$ balanced with wet synthetic air for $2 \mathrm{~h}$.

Fig. 10. Response transients of $\mathrm{EC}\left(\mathrm{N} / \mathrm{SnO}_{2}-\mathrm{h}\right)$ sensors $(\mathrm{N}: \mathrm{Ag}, \mathrm{Au}, \mathrm{Ir}, \mathrm{Rh}, \mathrm{Ru}, \mathrm{Pd}$, and $\mathrm{Pt})$ to (a) $500 \mathrm{ppm} \mathrm{CO}$ and (b) $500 \mathrm{ppm} \mathrm{H}_{2}$ in wet synthetic air at $30^{\circ} \mathrm{C}(57 \% \mathrm{RH})$. 
(a) Sensor element (electrochemical cell, EC)

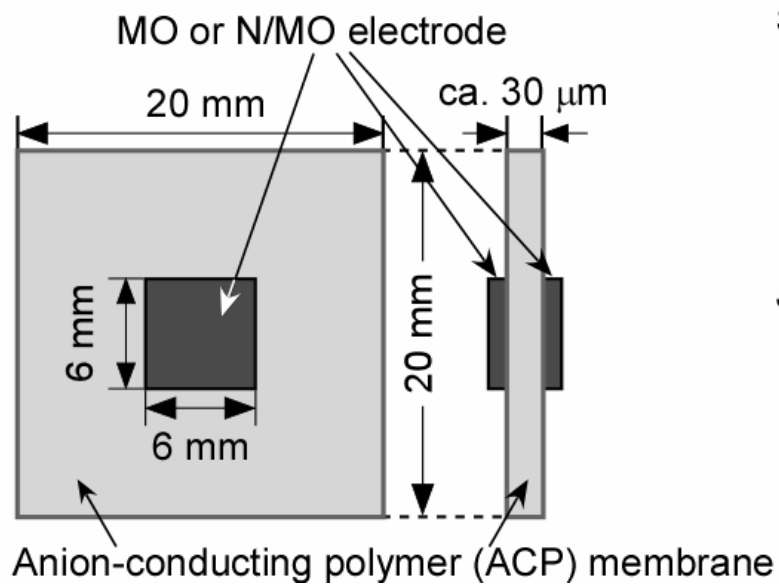

(b) Gas-sensing measurement system

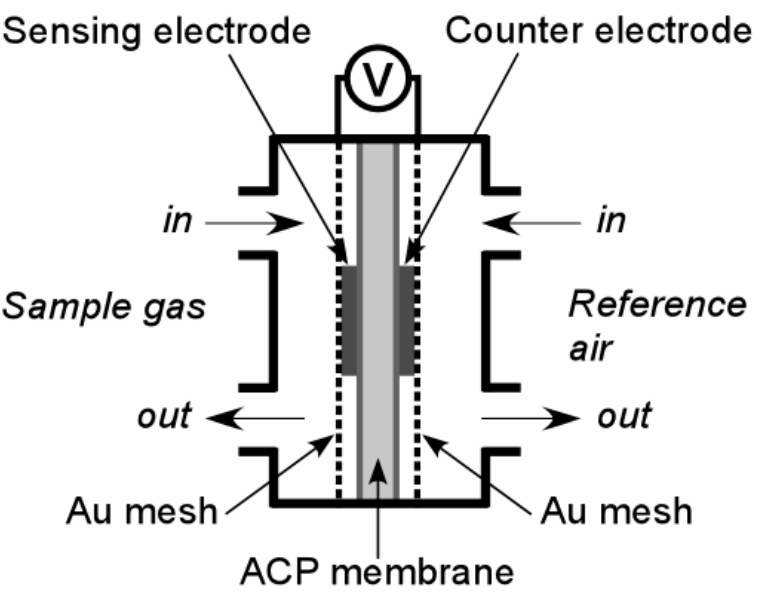

Fig. 1. Hyodo et al. 


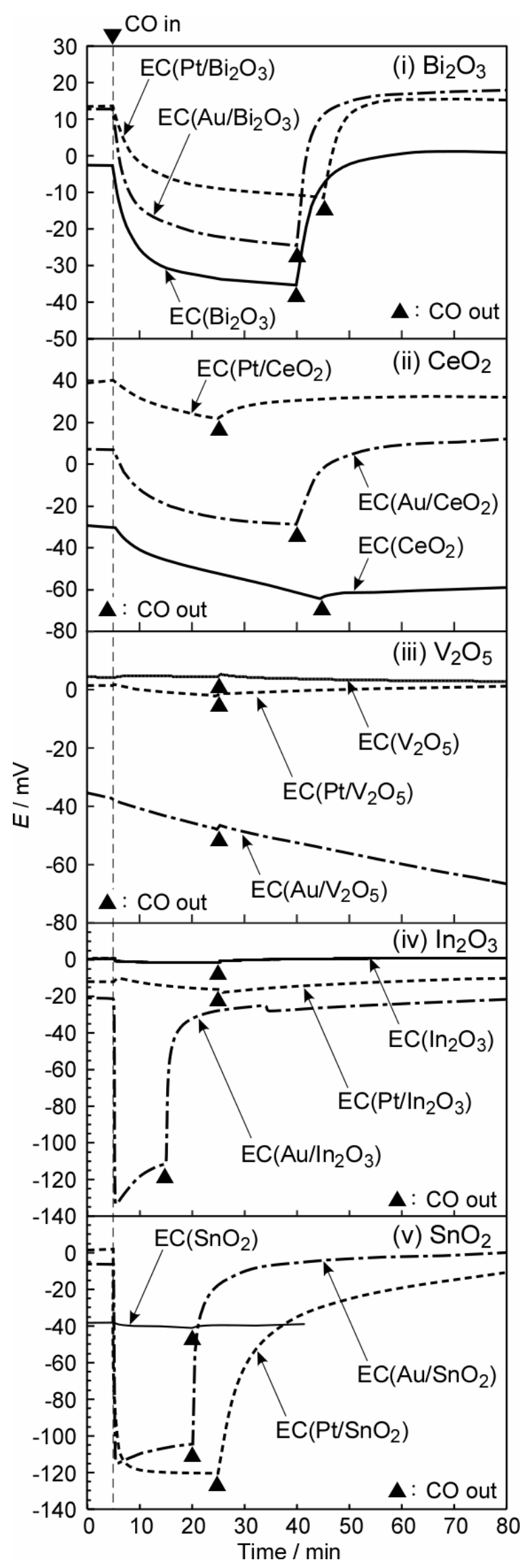

Fig. 2. Hyodo et al. 


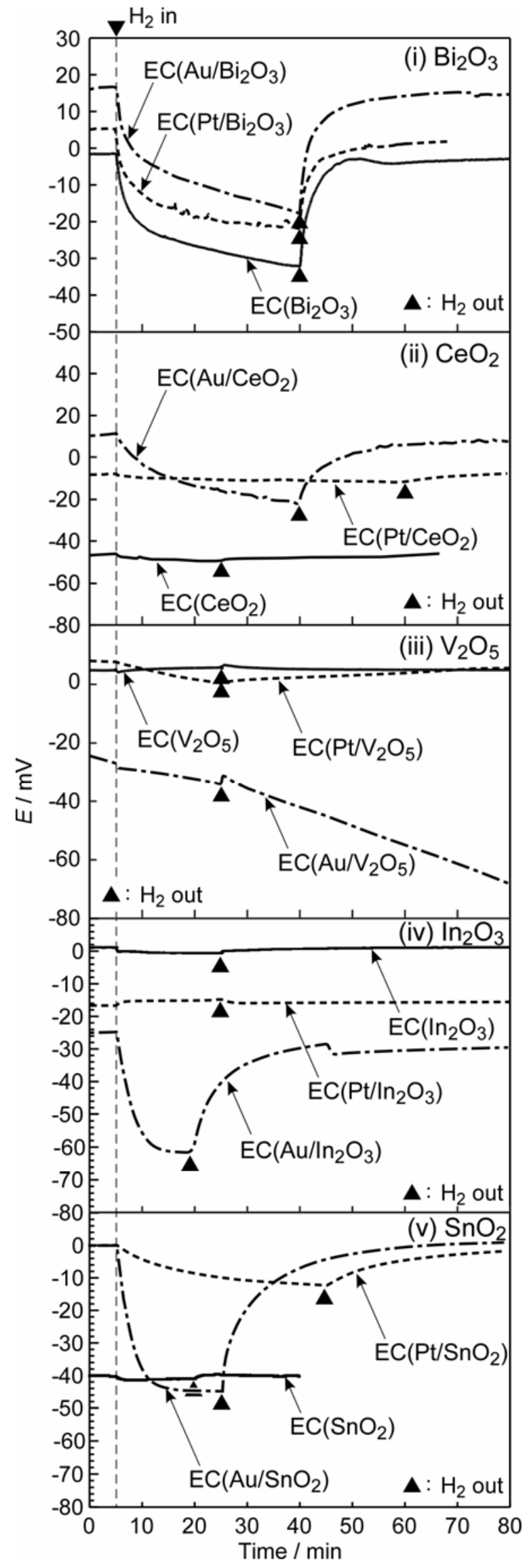

Fig. 3. Hyodo et al. 


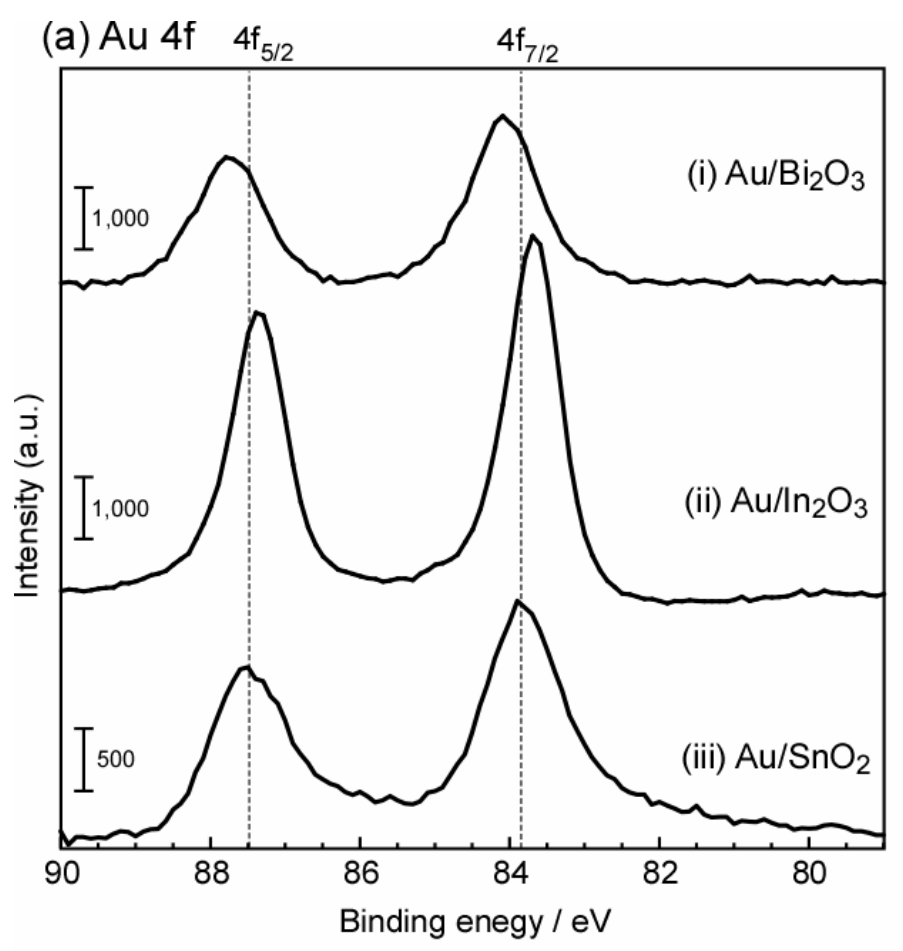

(b) Pt 4f

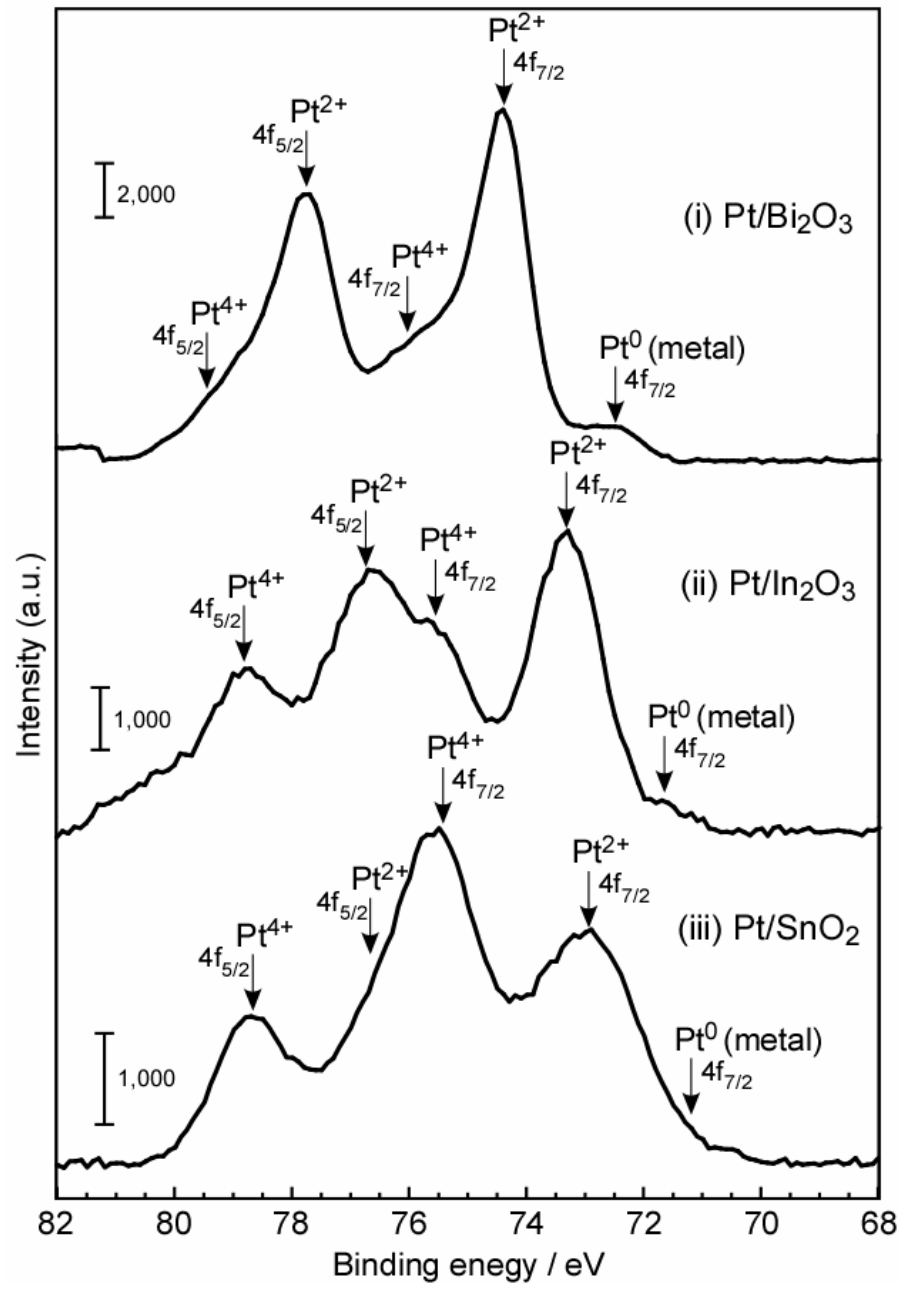

Fig. 4. Hyodo et al. 
(a) $B i f_{7 / 2}$

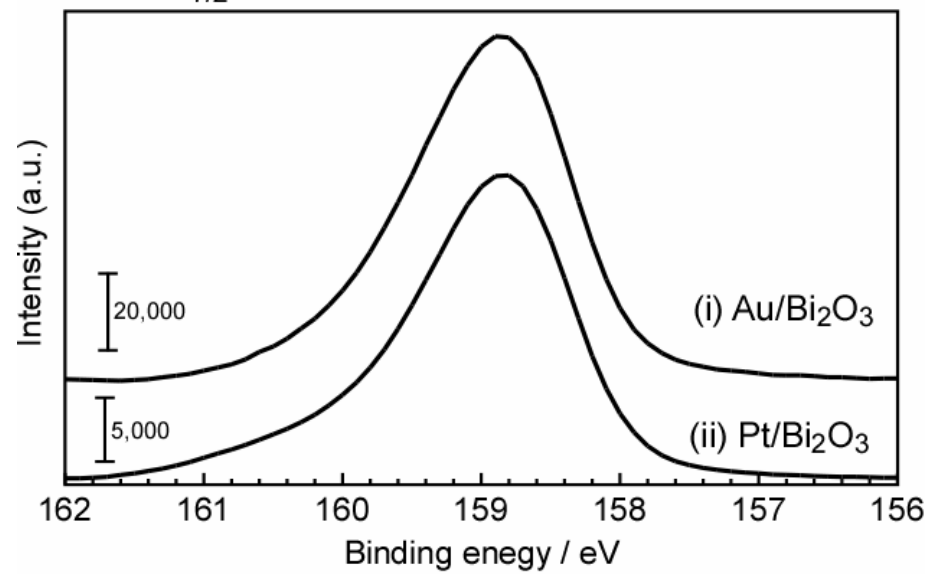

(b) $\ln 4 f_{7 / 2}$

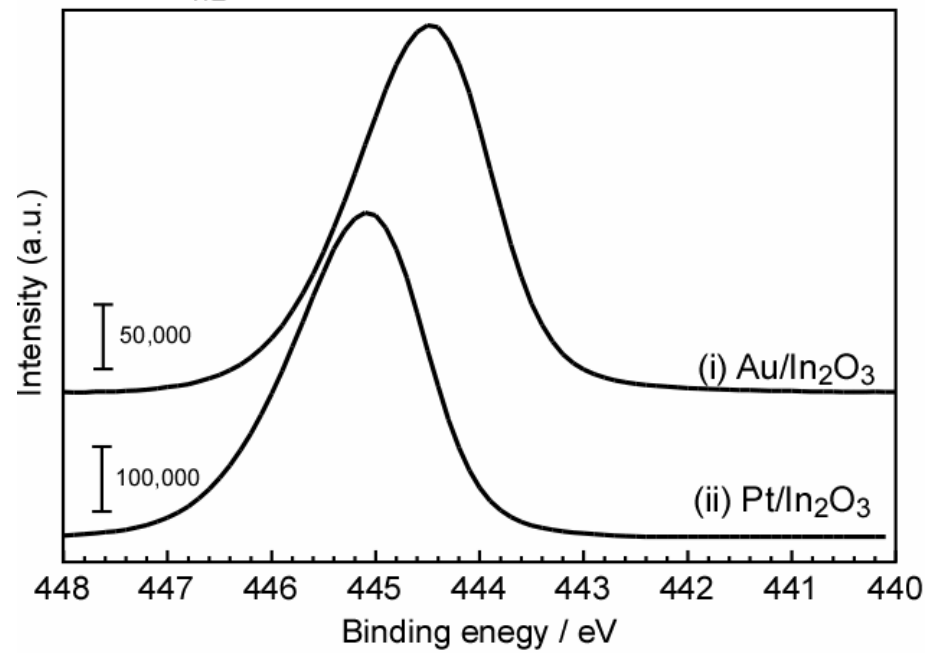

(c) $\mathrm{Sn} 3 \mathrm{~d}_{5 / 2}$

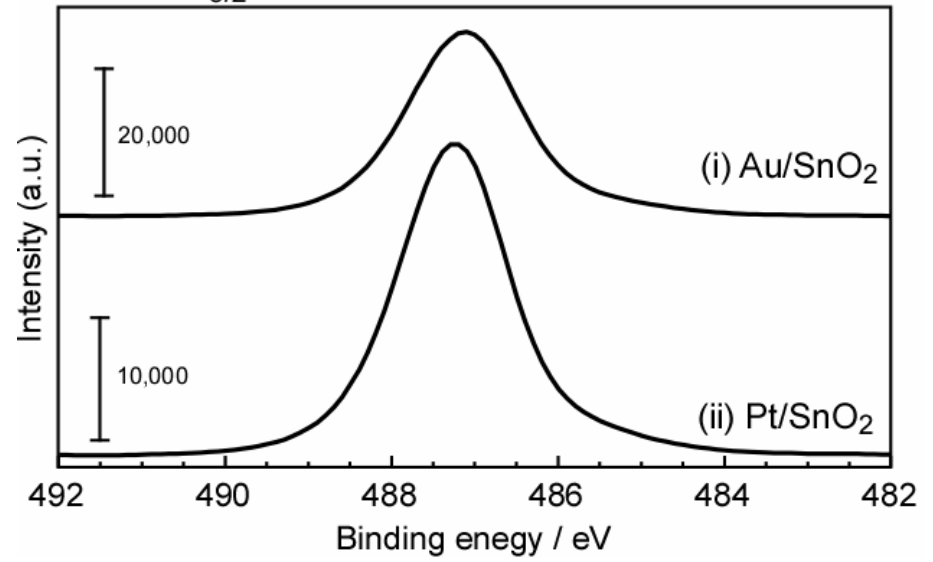

Fig. 5. Hyodo et al. 


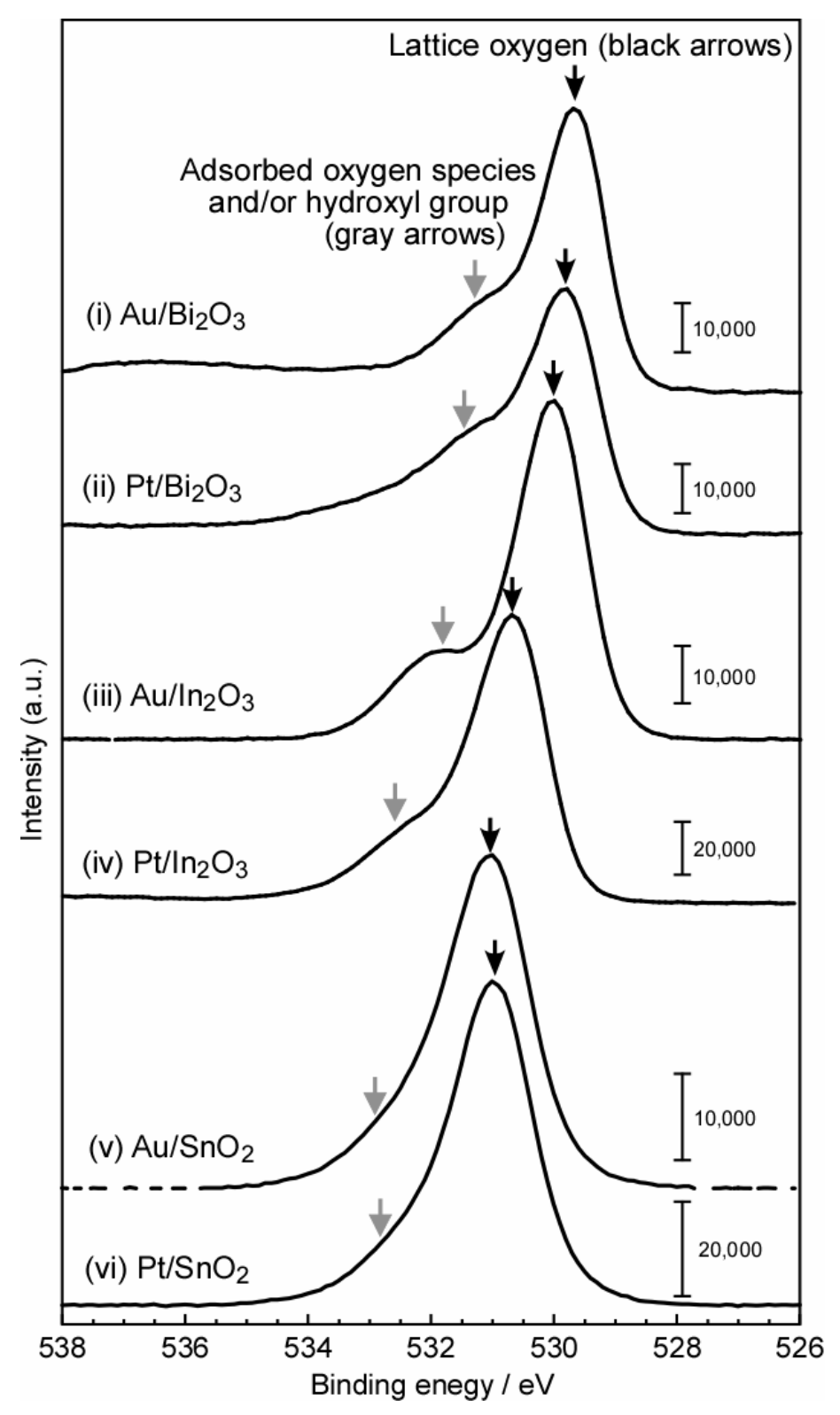

Fig. 6. Hyodo et al. 
(a) $\mathrm{EC}(\mathrm{Au})$
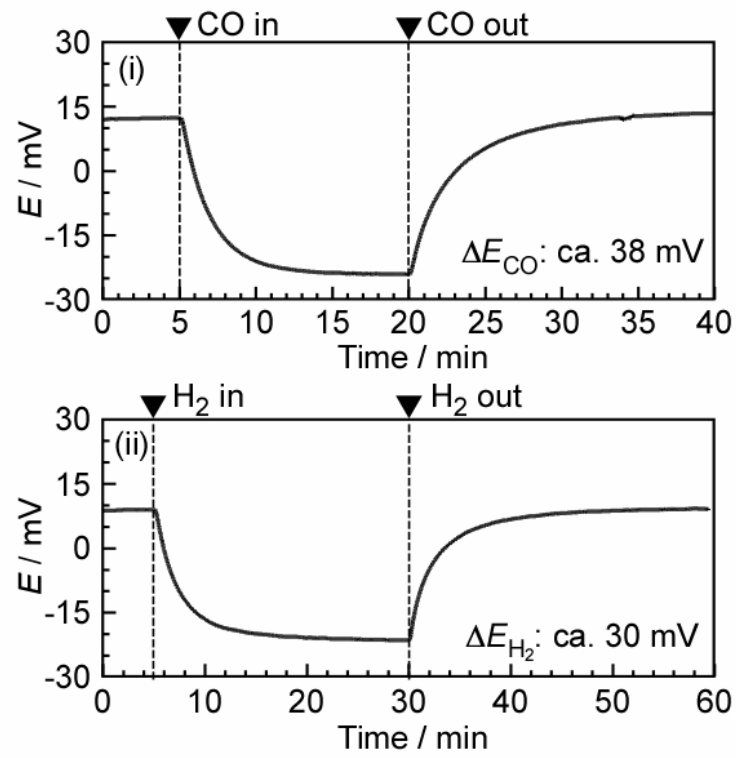

(b) $\mathrm{EC}(\mathrm{Pt})$
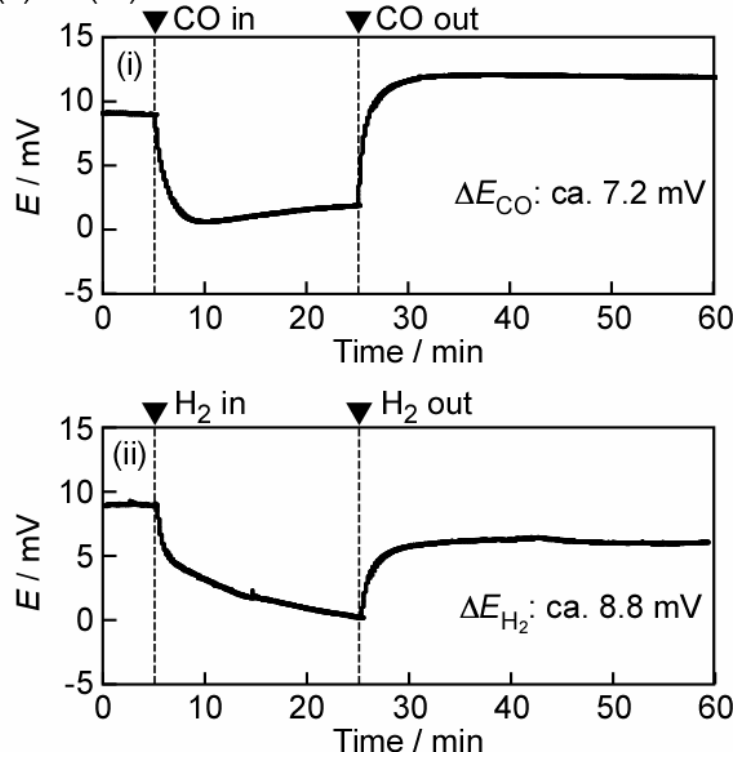

Fig. 7. Hyodo et al. 

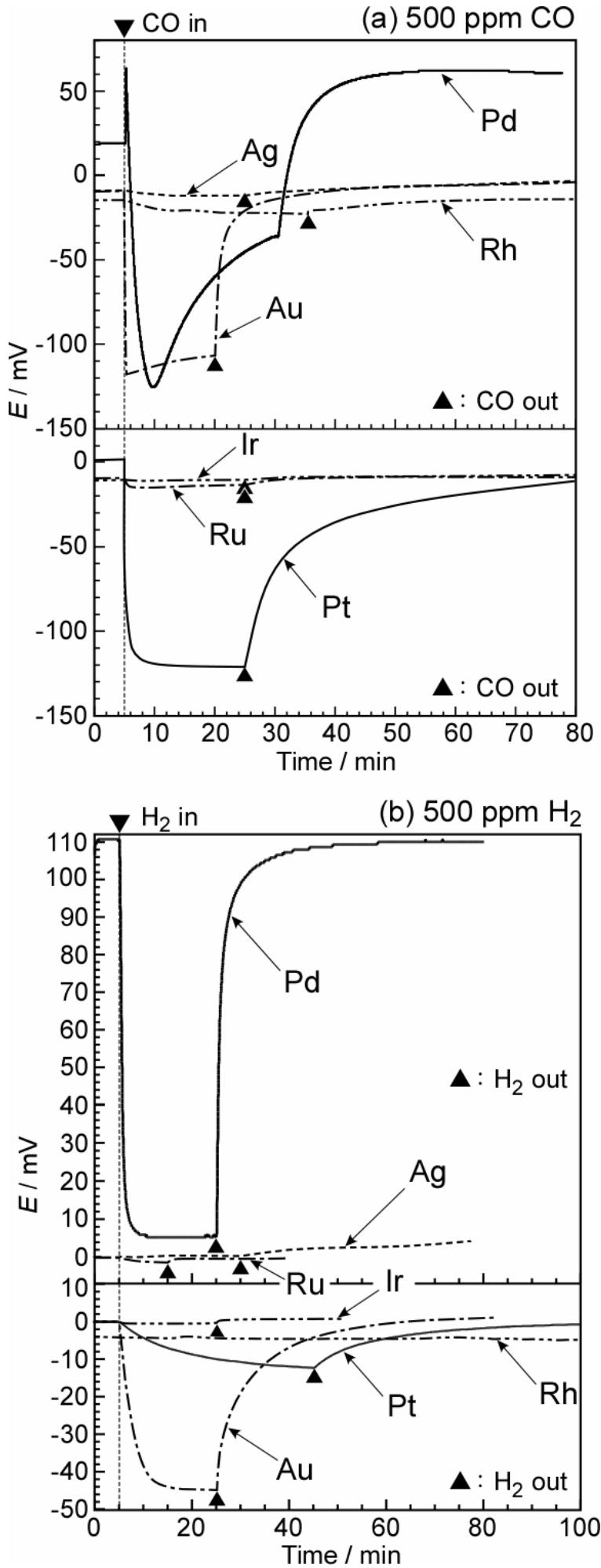

Fig. 8. Hyodo et al. 


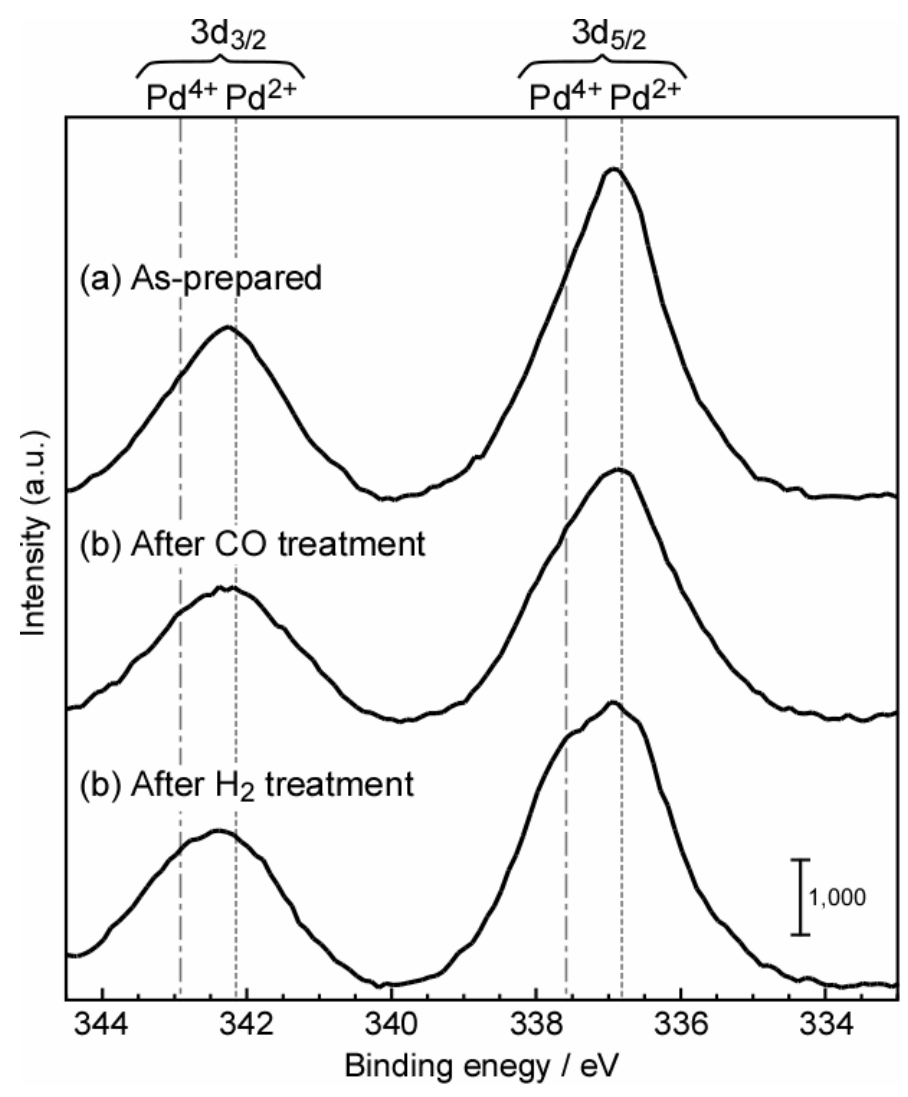

Fig. 9. Hyodo et al. 

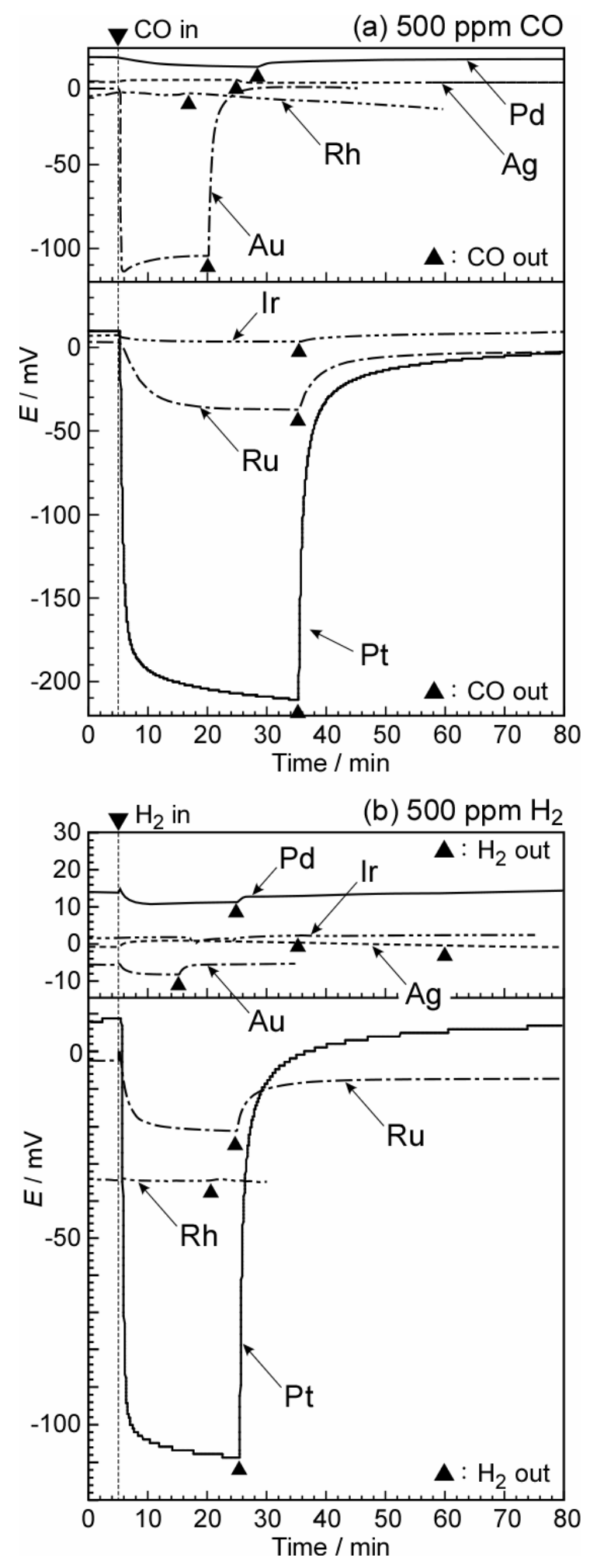

Fig. 10. Hyodo et al. 


\section{Supporting Information}

Potentiometric $\mathrm{CO}$ sensors using anion-conducting polymer electrolyte: effects of the kinds of noble metal-loaded metal oxides as sensing-electrode materials on $\mathrm{CO}$-sensing properties

Takeo Hyodo*, Mari Takamori, Toshiyuki Goto, Taro Ueda, and Yasuhiro Shimizu

Graduate School of Engineering, Nagasaki University

1-14 Bunkyo-machi, Nagasaki 852-8521, Japan

*Corresponding author: hyodo@nagasaki-u.ac.jp 


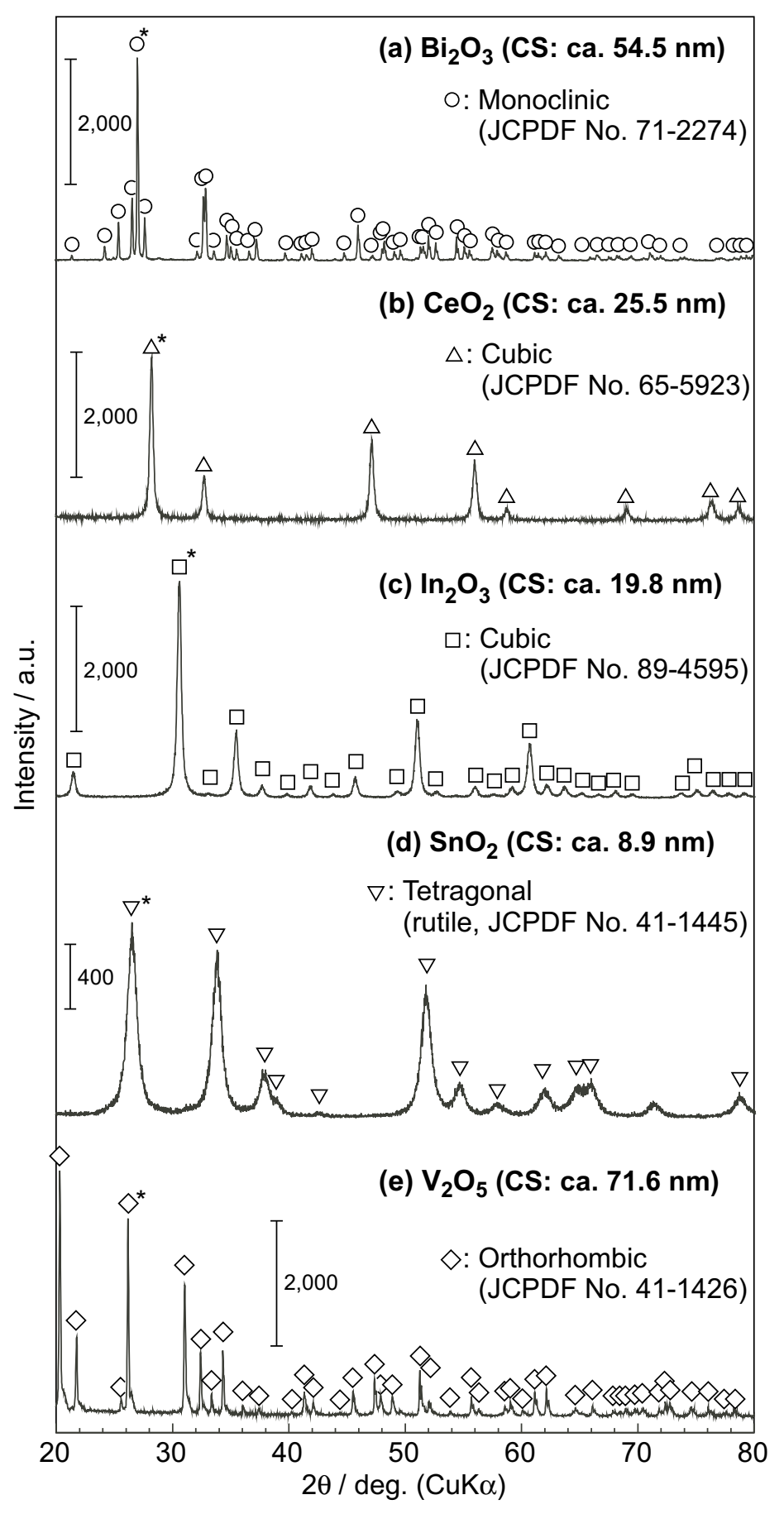

Figure S1. XRD spectra of all metal-oxide (MO) powders, together with crystallite sizes (CSs). *: Diffraction peaks utilized for calculation of CSs. 
(a) $\mathrm{N}_{2}$ adsorption-desorption isotherms

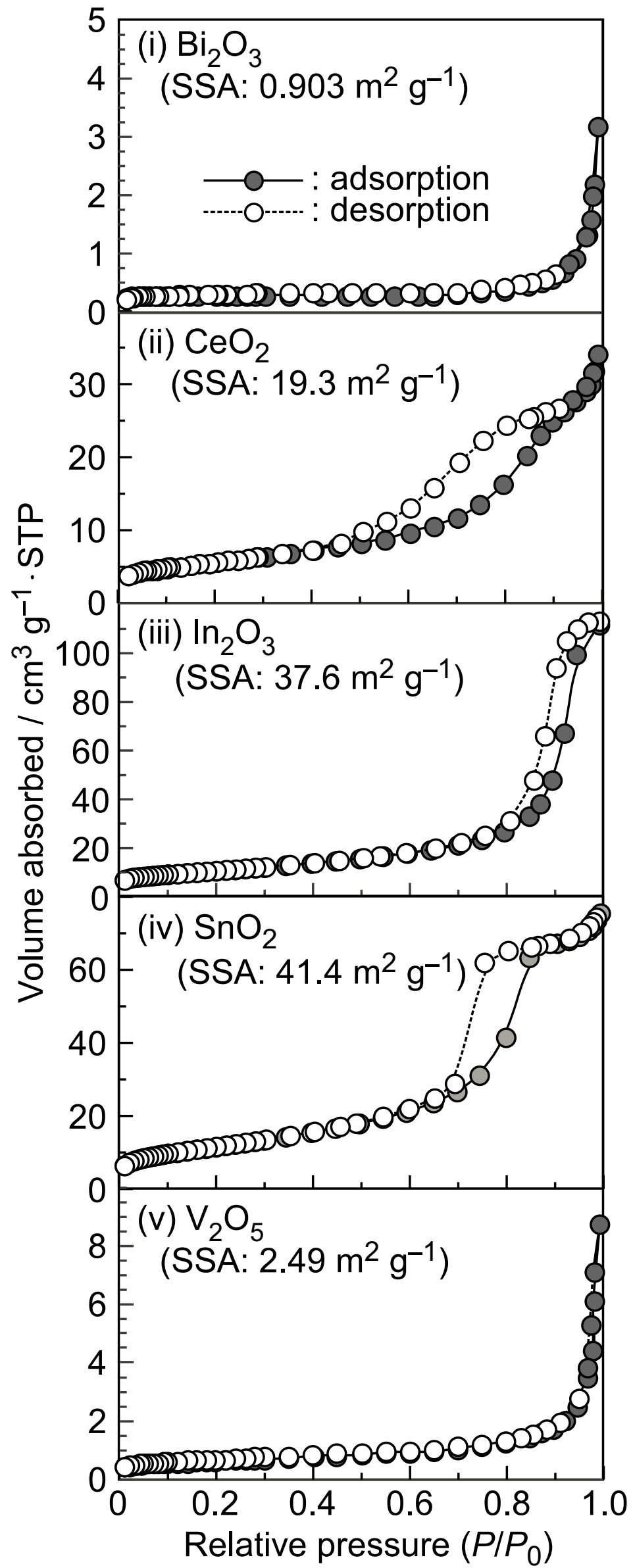

(b) Pore-size distributions

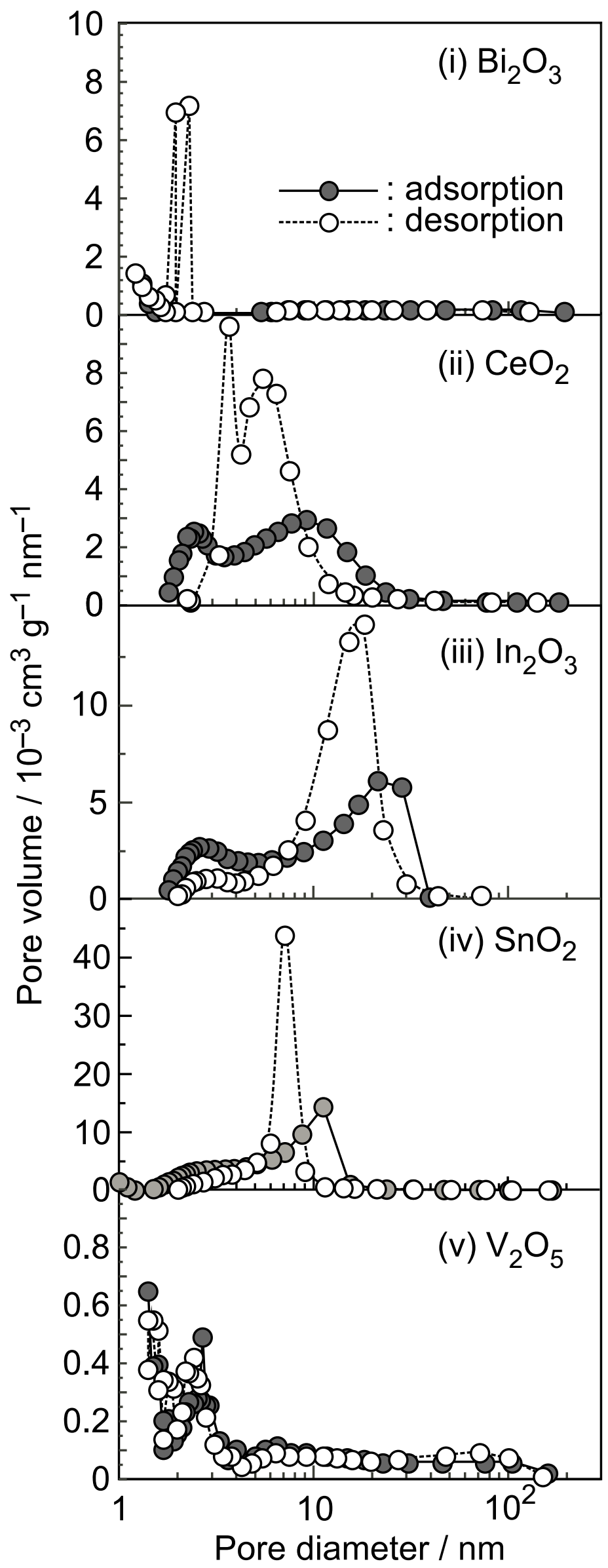

Figure S2. $\mathrm{N}_{2}$ adsorption-desorption isotherms with specific surface areas (SSAs) and pore-size distributions of all MO powders. 


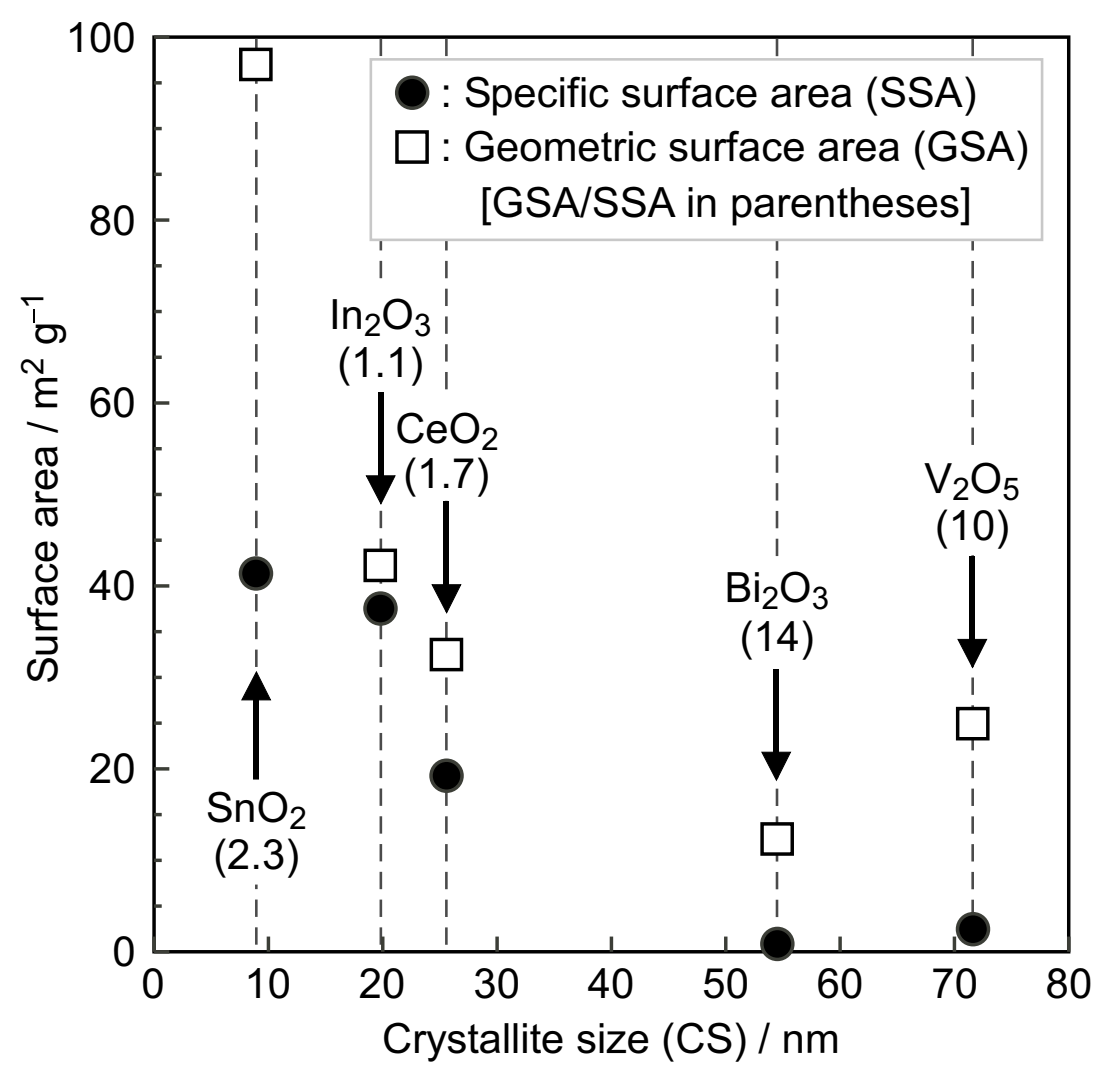

Figure S3. Relationship between two kinds of surface areas (SSA and GSA) and CS of all MO powders. 

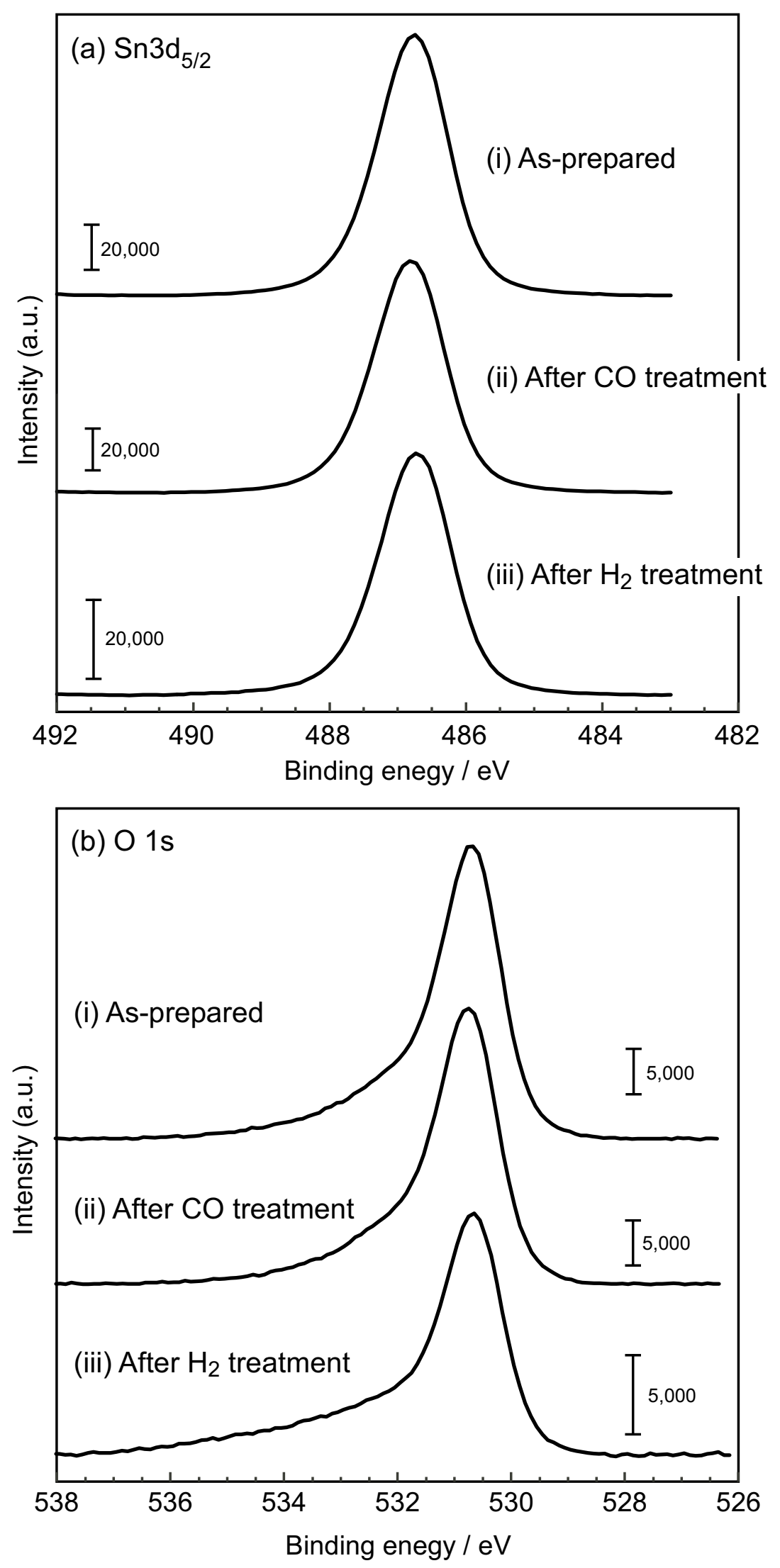

Figure S4. XPS spectra of $\mathrm{Sn} 3 \mathrm{~d}_{5 / 2}$ and $\mathrm{O} 1 \mathrm{~s}$ of $\mathrm{Pd} / \mathrm{SnO}_{2}$ sensing electrode of $\mathrm{EC}\left(\mathrm{Pd} / \mathrm{SnO}_{2}\right)$ sensor before and after exposure to $3000 \mathrm{ppm} \mathrm{CO}$ and $\mathrm{H}_{2}$ balanced with wet synthetic air for $2 \mathrm{~h}$. 